\title{
The Role of Student Activities in the Development of Life Skills among Disabled Students at King Abdulaziz University
}

\author{
Dr. Lina Omar Bin Saddiq \\ Associate Professor of Special Education, \\ Department of Special Education, \\ Faculty of Educational Graduate Studies, \\ King Abdulaziz University, Saudi Arabia
}

Doi: 10.36941/jesr-2020-0oo8

\begin{abstract}
The present study aimed to define the role of student activities in the development of life skills among disabled female students. It covered a sample of intentionally selected students with (vision, hearing, motor, and multisensory) impairment and registered in the Deanship of Student Affairs for the Bachelor Degree (Regular and External Study) for the second semester of 2017/2018 at King Abdulaziz University. To achieve its objective, the study applied an intake form to define the most important information to be collected representing the variables, life skills' inventory (Bayounis, 2016), and open-ended questionnaire of student activities developed by the author. It concluded that disabled students highly needed to develop life skills. The student activities highly promoted life skills according to the (type of disability, major, nature of the study, and number of activities) variables. The study recommended preparing a teacher's guide of student activity implementation considering the development of life skills that are appropriate for the disabled students.
\end{abstract}

Keywords: Student activities, Life skills, Disabled students

\section{Introduction}

The disabled are an important segment of the society. They are an integral part of the Saudi national fabric. The disabled students are included in the educational system of any university to meet their needs and requirements from enrollment to graduation because they are expected to assume great responsibilities. The university prepares them academically and qualifies them to the labor market to hold the positions that match their needs. As a result, the community's burden is alleviated, and the social and psychological implications due to disability are limited.

Modern educational approaches call for linking the educational institution to the surrounding environment because curricula only do not provide the required experiences and contexts. Student activities help achieve the educational aims of building the balanced personality of the student. Thus, the university- that holds a large number of disabled students- tries to involve their opportunities for education and training. In other words, the activities are designed in a way that meets the disabled students' needs (Qasayma and Akbar, 2010).

Student activities are one of the items that offer comprehensive development of the students. Simply, they employ the students' powers, achieve their attitudes and self-realization, and give a sense of social entity (Othman and Qamar, 2009). Many learning theories report the importance of activities' practice in the university life that develops personality, helps students acquire experiences 
and skills, and achieves integrated development and desired change.

Student activities make the university an indivisible community where students are trained in university and social life. They also aim to achieve many objectives that consider acquiring the different skills, disseminate a sense of community and cooperation, and support personality based on the challenges, problems, and responsibilities they encounter. That is, these activities are important because they employ free time for the benefit of the students and the university environment, making them more aware of themselves. Consequently, students become more efficient in handling different life situations.

Maziu (2014) argues that activating student activities is one of the most important means of skill acquisition. She recommends interest in these activities that play a significant role in acquiring the positive skills and values for qualifying them to maintain the safety and advancement of society. They are important for students, in general, and the disabled, in particular. They redress those students' defects and alleviate disability, hindering social adjustment. To put it differently, the practice of student activities is one of the most important and fastest means of inclusion, if correctly applied, especially those common ones with peers.

Furthermore, developing the desired life skills is an important issue that requires seeking promotion mechanisms due to their increasing number worldwide. All efforts should be incorporated to create a suitable environment for them. The interest in life skills is a significant modern approach to education globally that qualifies the students comprehensively. In addition, including life skills in the curriculum is of great significance as an important educational outcome and required for the learners at any stage. The students need these skills throughout their lives and in their everyday life affairs to achieve a comprehensive and sustainable education.

Abdulmoatey and Mostafa (2007) report the importance of developing syllabi that promote life skills because they are important for the learner. They help boost scientific thinking skills, decisionmaking, problem-solving, self-understanding, and rationalization of consumption. Alnajey (2009) stresses the importance of developing life skills because acquiring any life skill creates a positive attitude towards it, highlights its impact and benefit, and provides related functional knowledge and information.

According to Saad-eddin (2007), Ouda (2008), Hasan (2009), Algedeby (2010), life skills are essential. They help develop the attitude towards the subject, offer a better life rich in positivity and productivity, and enable the person to manage interaction with others and the environment. Furthermore, they promote skills to open new horizons for work, life management, self-adaptation, and adjusting to modern changes and life requirements. Life skills enable the person to solve life problems and practice different thinking skills.

Alattom (2008), Abdulmoatey and Mostafa (2008), and Abuhajar (2011) argue for activating the role of student activities in developing life skills, as well as motivating students to join and participate into these activities as a learning requirement that helps connect the student to the environment and local community problems. They help handle and solve some problems and strengthen the relationship between the educational institutions and the local community. Consequently, a person acquires life skills to communicate and interact positively with others, live better, and manage dayto-day situations effectively. Student activities motivate the person to solve community problems and take part in the events, promoting self-confidence and pride. In other words, the person's success in the future largely depends on experience and life skills.

Life skills have received extensive attention in international and regional forums. UNICEF (2005) reports that (146) countries- of those adhering to free education- agreed on including life skills as a means of youth empowerment against the situations they encounter and providing them with knowledge based on proper behavior. The project of Utah State Office of Education (2006) stressed the importance of equipping public education students with basic life skills, including personality, communication, thinking, and independence (UNICEF, 2005; Utah State Office of Education, 2006).

The author finds out that King Saud University, KSA has a specialized deanship, known as the "Deanship of Skills Development". It holds training workshops on self-development based on student 
and faculty needs. Accordingly, student activities and life skills are important. Lack of studying life skills plays a part in embedding the advancement of societies (Wafy, 2010).

Therefore, a study should be conducted to identify the role of student activities in the development of life skills among disabled students. To the author's knowledge, no studies have addressed the role of student activities in the development of life skills among university students.

\section{Statement of the Problem}

Universities are interested in student activities and their moral and financial support. They are keen on including these activities in the study plans and programs. However, many studies report the weak student participation, as well as poor content and effectiveness of student activities. They agree on the poor university study in developing the life skills of students.

Alharethy (2010) concludes that the graduates of educational institutions lack skills. Many of them fail in their personal and professional life because of the lack of self-awareness and effective communication skills. Bakheet (2000) recommends including activities that help develop life skills among the students of King Abdulaziz University in student activities. Baroum (2012) argues that the lack of life skills is one of the most significant problems that the student encounters. Kagan (2013) reports a crisis in life skills. They should be promoted for the success of students, community, and productivity increase. Moreover, the discussion of educationalists, governments, and employers continues on the short inventory of life skills.

Bayounis (2016) concludes that an intermediate to a high need for life skills among the students of King Abdulaziz University. The students who are capable of understanding and utilizing life skills, along with their academic qualifications, gain better education and work opportunities. Although student activities play a significant role for university students in general, their significance for the disabled is higher. They redress the defects and alleviate the disability hindering social adjustment. The practice of student activities is one of the most important and fastest means of inclusion, if correctly applied, especially those common ones with peers.

The problem of the present study has been defined in the problems of the disabled students, such as lack of many life skills compared to the healthy, resulting in education-related problems or adjustment with post-graduation community requirements. Interestingly, they play a role in the development of life skills in a way that qualifies students for the labor market or social and family life in the future. They are important for academic and practical life, whether hand, intellectual, or social. Our education system neglects and does not provide learners with most life skills. Thus, the educational institutions seeking to keep pace with and leading change should include and teach a set of life skills to prepare students for the future. Students actively participate in building society to be healthy and positive. To confront this problem the present study raises the following major question:

What is the role of student activities in the development of life skills among disabled students at King Abdulaziz University?

\section{Questions}

1. What is the role of student activities in the development of life skills among disabled students at King Abdulaziz University?

2. What student activities developing life skills do meet the needs of disabled students according to the (type of disability, major, nature of the study, and number of activities) variables at King Abdulaziz University?

3. What are the most required life skills by disabled students at King Abdulaziz University?

\section{Objectives}

The study aimed to define: 
1. The role of student activities in the development of life skills among disabled students at King Abdulaziz University.

2. The student activities that develop life skills to meet the needs of disabled students according to the (type of disability, major, nature of the study, and number of activities) variables at King Abdulaziz University.

3. The most required life skills by disabled students at King Abdulaziz University.

\section{Significance}

The study is significant because it addresses the following issues:

\subsection{Significance of the university stage}

University is one of the most important stages in the life of young people. It qualifies them for worklife and enables them to play their social roles effectively and efficiently. Moreover, it plays a significant role in their political, national, and social education by providing the necessary knowledge and equipping them with various values and skills to make them good citizens, develop personalities, and promote capabilities. As a result, young men engage in different fields and help advance society (Alharby, 2017).

University education is responsible for preparing learners not to have knowledge only. Rather, they should have the tools and skills of knowledge. In other words, they are not only consumers but producers of knowledge, as well. Therefore, student activity has great importance in university programs because of its effective role in achieving such educational objectives (Mujahid, 2008).

Undoubtedly, the competition of universities for the quality and appropriateness of outcomes for the labor market necessitates preparing students who effectively participate in community development. That is, universities shall equip the students with the latest updates at the age of knowledge explosion to enhance their level through innovation and reconsidering the education systems and skills. Accordingly, students are developed and prepared for challenges (Alhelwa, 2014).

The author believes that the university is an essential institution in any society. It is the highest educational and formative institution that graduates and qualifies generations for the different jobs to meet society needs and interests. It also ensures the society's continuity and existence. No other institution can play the university's role. In other words, the other institutions need the services that the university offers and ensures.

\subsection{Significance of student activities}

Educational articles and studies report the importance of different student activities to meet learners' needs and attitudes. They are highly significant for the natural development of the student physically, mentally, emotionally, and socially for the best interest of the student and society. Thus, the universities of both advanced and advancing countries are keen on including student activities in their plans and programs for students to achieve a set of educational goals. The programs of activities should vary quantitatively and qualitatively to primarily develop personality aspects and build a good citizen who is aware of rights and national duties (Maziu, 2014).

To put it differently, student activities actively define student abilities and attitudes, refine skills, and give the distinguished students the opportunity of innovation and excellence through programs that match their talents and abilities (Azzobiany, 2002). The author believes that the practice of cultural, social, sports, art, and other activities give the student the opportunity to acquire many life skills that are required for communication in society. 


\subsection{Positive attitude towards the disabled}

Rehabilitation of the disabled is a cultural challenge for nations and communities because it is a humanitarian issue primarily. It can hinder national progress. Furthermore, the supporting services that the university offers to the disabled are necessary for making the best use of personal and social adjustment (Mansour, 2010). Therefore, the present study is interested in the disabled students who have received greater interest recently.

The author argues that the present study is significant because it addresses the growing international interest in the disabled, rehabilitation, and employing their limited capabilities for the adjustment with the environment and inclusion in the society. She believes that training and rehabilitation are a basic right for the disabled. She also reports the necessity of developing and implementing the programs required for social life rehabilitation and preparation for self-reliance in daily life affairs, as possible.

\subsection{The need to develop life skills among the disabled}

The development of life skills among the disabled is important because they enable the disabled to work easily and promote the mastery of the different works. They also give a greater opportunity for autonomy, self-reliance, enjoying free time, self-confidence, work with others, innovation, and creativity (Shaaban, 2009; Aly, 2014). The author believes that the disabled can be helped feel efficient and effective by teaching many skills. As a result, he/she has self-reliance, receives appreciation, and lives a better life.

Life skills are required for the disabled to adjust with themselves and the community and to help them handle everyday situations and life problems. They are a set of skills related to the environment, including knowledge, values, and attitudes acquired in an intentional and organized way through activities and applications. Thus, it is important to conduct the study by investigating the reality of student activities at King Abdulaziz University, as well as their role in improving the life skills of disabled students. Furthermore, it is a significant study theoretically and practically.

\subsection{Theoretical significance}

a. It is- to the author's knowledge- the first study in Saudi Arabia about the effectiveness of student activities in the development of life skills among disabled female students.

b. It may help enrich the theoretical frameworks related to the basic and important fields of student activities among disabled students.

c. It adds to the educational literature related to the different life skills among all categories of disabled students.

\subsection{Applied significance}

a. It evaluates life skills among the different categories of disabled students and defines the most significant ones for social adjustment.

b. It may guide the planners of student activities programs' in the Deanship of Student Affairs and Special Needs Center to the interest in developing and varying student activities qualitatively and quantitatively.

\section{Limitations}

The study was limited to:

- Human limits: All visually impaired and blind students with multi-sensory impairment at the departments of (Media, Psychology, Islamic Studies), Faculty of Arts and Humanities, 
Faculty of Economics and Administration, and Faculty of Sciences; the deaf and hearingimpaired students at Design and Arts Department, Faculty of Education; motor-impaired students at the scientific faculties; the students registered in the Deanship of Student Affairs for the Bachelor Degree (Regular and External Study).

- Temporal limits: The second semester of 2017/2018

- Subject limits: Student activities offered by the deanships and centers of Women's Campus (Sulaymaniyah), King Abdulaziz University.

\section{Definition of Terms}

- Student activities: They are procedurally defined as a set of extracurricular programs offered by the Deanship of Student Affairs and the Center of Special Needs for disabled students in 2017/2018.

- Life skills: They are procedurally defined as a set of nonacademic and cognitive abilities and attitudes that enable disabled university students to have positive social adjustment. Thus, they can effectively handle everyday issues and challenges to promote physical, mental, psychological, personal, social, and technical health. They are defined by the total score of the students based on their responses to the items of the life skill scale.

- Disabled students: They are procedurally defined as the blind, visually-impaired, motorimpaired, deaf and hearing-impaired students. They also include the students with one or multi-sensory impairment at the humanities and scientific faculties- that they are allowed to join- for Bachelor Degree (Regular and External Study), King Abdulaziz University.

\section{Theoretical Framework}

Many psychological and educational studies report the need to consider the needs, attitudes, and capacities and to cover the different personality aspects of the student. They stress the importance of practicing student activities. Furthermore, the extracurricular guided activity is a fertile educational field where the students express hobbies, meet needs, develop, and acquire experiences and educational situations that are difficult to learn in the classroom.

Some studies, e.g. Kelab (2018), Alfera (2015), Maziu (2014), Abdulmonem (2013), Shaldan and Alnadeem (2013), Attahrawey and Abukosh (2013), Hammad and Allouh (2013), Abudalyouh (2011), Abdulhaseeb (2010), Abdulaleem (2007), Qanadeely (2006), and Mina (2004), argue that the students involved in student activities enjoy group adjustment and loyalty, facilitating the transfer of this spirit to the society. Furthermore, these activities promote the skills of interaction and cooperation; enhance the ability to planning and making group plans; expose capabilities, aspirations, and attitudes; acquire selection, responsibility, and basics of debate; learn to employ free time. The students are high academic achievers, positive towards peers and teachers. They enjoy leadership, emotional stability, self-confidence, decision-making, resistance, and positiveness to peers. In addition, these activities enhance social skills, motivate self-guidance, and implant the desired moral, social, and spiritual values through real practice.

To achieve their goals of developing students, as well as acquiring many skills, values, and attitudes in higher education institutions, student activities should be set based on certain basics and criteria. Aljaweesh (2007) reports that:

1. They should have one defined goal that adheres to the religion and culture of the society.

2. A written and announced plan should be made regulating student activities.

3. The activities should match the human and financial capabilities of the educational institution to be applicable.

4. The students engage in setting, planning, implementing, and evaluating student activities.

5. The administration concerned with student activities should have the motive to implement the activities. 
6. The activities should vary, consider the students' differences, and have the opportunity of selecting the activities that meet their attitudes and desires.

7. The youth welfare specialist observes these activities.

8. The student activities relate to the academic study and help achieve the objectives.

9. They are estimated on the educational and social not the financial value. That is, their activities are environment-related.

Arrefaey (2007) categorizes student activities into the following fields:

1. Social activities: The students are urged to collaborate, develop human relations, build a normal personality, deepen the feeling of responsibility towards the community and the environment, and acquire new skills in the health and social fields.

2. Scientific activities: They seek the development of research and innovation, link theory to practice, develop manual skills, benefit from environment service, and enhance the scientific trends, e.g. objectivity, among the students to help establish a productive and innovative scientific community.

3. Cultural activities: They introduce the Islamic and Arab culture, instill a love of reading, and promote the skills of library use.

4. Scouting activities: They aim to introduce the students to scout and its social roles, train students in discipline and cooperation, promote courage and patience, connect them to nature, train and enhance their volunteer work skills.

5. Sports activities: The students make the best use of time to keep healthy, satisfy needs and attitudes, develop sportsmanship, train in discipline, and have self and emotion control.

6. Artistic activities: They aim to satisfy the students' artistic attitudes, develop artistic culture, promote awareness, and appreciate work value.

7. Professional activities: They aim to instill the love of manual labor, introduce the available job opportunities, train in much-needed manual work to meet the needs of local markets, and disseminate the concepts of prevention and safety at work among students.

8. Computer activities: They introduce the students to the computer, as well as its uses and significance to facilitate and organize the required work for the sake of achievement, knowledge, or entertainment.

9. Islamic awareness activities: They help deepen the Islamic concepts among students, inform them of the religious issues, protect them against deviant ideas and behaviors, and guide them appropriately.

In turn, student activities perform many functions. For example, educationally, student activities help give opportunities to apply the values and principles and equip students with skills and experiences within the desired attitudes, e.g. respect and confidence. Psychologically, they develop psychological construction, overcome psychological problems, including shyness and introversion, and enhance motivation to satisfy the needs of students. Socially, student activities promote cooperation, satisfy social needs, such as belonging, and develop the social skills of students to become active citizens. Professionally, student activities allow the students to identify the different jobs, select the ones that suit their interests and abilities, and form positive attitudes towards planning for the future (Mustafa, 2017).

The student learning outcomes of the national qualification and academic accreditation of higher education institutions states, "student learning outcomes should match the national qualification requirements". It classifies the expected learning outcomes in four fields. Bayounis (2016) reports that they are:

1- Knowledge: The student's ability to retrieve, understand, and deliver information.

2- Cognitive skills: They include critical and creative thinking, problem-solving, and drawing correct conclusions using different sources.

3- Interpersonal and responsibility skills: They include self-learning, continuous personal and professional development, teamwork, and leadership.

4- Psychological-motor skills: They are limited to some programs, such as motor-psychological 
skills of surgeons.

In other words, having these skills enables the students to retrieve and apply knowledge in their professional and personal life for many years of graduation.

The inclusion of the disabled in education is a natural extension of their life with family and peers before joining the different educational stages. It is a natural rehabilitation means that matches their practical and social conditions after graduation. On the contrary, the exclusion is an arbitrary action that shows discrimination and highlights differences, hindering rehabilitation for a natural life in the future (Alqraiti, 2010).

Abulelaa (2018) argues that the disabled participate in student activities for many reasons, such as:

1- Identifying and developing different talents.

2- Engaging with peers in different activities and overcoming a feeling of exclusion.

3- Making friends when being at colleges with students at other departments.

Thus, the author concludes that disabled students are motivated to engage in student activities. This conclusion is in line with the trends calling for the inclusion of the disabled in education, providing them with equal educational opportunities. They stress the right of education based on justice, equality, and equal opportunities regardless of the type of disability and the socio-economic or cultural level, qualifying them for living positively and achieving stability and social cohesion.

The universities, in both developed and developing countries, are keen on including student activities in their plans and programs to achieve a set of educational goals, equipping the students with many attitudes, values, and life skills. Life skills are the skills concerned with building an individual capable of taking responsibility, handling everyday issues personally, socially, and functionally, and creative interaction with the community and its problems sincerely (Ministry of Education in the Sultanate of Oman, 2010).

There are many different concepts of life skills because of the lack of an inventory of them. Wafy (2011) defines the following characteristics:

1. Life skills vary to cover the different physical and non-physical aspects concerning satisfying the individual's needs and requirements of interaction with life and development.

2. They differ from a community to another depending on development. They also differ from time to another because the primitive man's need for reading and writing appeared when encountering the importance of recording history.

3. They are based on the nature of the correlation and affect the individual and the community.

4. They help adjustment, successful interaction with life and development of lifestyles. In other words, the individual handles traditional life situations in new and developed ways.

The author concludes that life skills comprise the cognitive components of behavior selection, the emotional components of selecting a certain behavioral pattern, and the skillful component of implementing the skill.

Many educators and specialists argue for equipping students with life skills to define different trends in their education. Alnajey (2009) reports four of them. First, the direct trend means teaching life skills as a separate course. Second, the bridging trend agrees with the direct one in delivering a separate course of life skills but links and integrates the course and contents to other courses. Third, the fusion trend combines direct and bridging trends. A life skill is taught directly while teaching any academic content. Moreover, the content should be redesigned in a way that helps achieve life skills learning. Fourth, the enrichment trend is concerned with teaching life skills through multiple curricular and extracurricular enrichment activities with/without school supervision, such as holding standardized training programs in life skills. The author adopts the fourth trend that teaches life skills through designing the appropriate educational activities according to the steps reported by Abdulmoatey and Mostafa (2007) concerning defining the life skills for university students and selecting the appropriate content for development using student activities.

Masoud (2002) argues that acquiring life skills is important because they achieve integration 
between the educational institution and life, embodying learning function that is linked to learners' needs, everyday situations, and community needs. They also allow the student to live in a better way, especially at this age of ongoing knowledge and technology explosion. Thus, individuals should be well-prepared and capable of adaptation and interaction with such changes and acquiring first-hand experience through interaction with people and phenomena. Moreover, they make learning meaningful and exciting, make the individual feel community problems and solutions, and allow the benefit from the available capabilities that boost comprehensive development at all levels.

Abdulmoatey and Mostafa (2007) reports that UNICEF supports an approach to understanding life skills through the following steps: Defining the psychological, social, and personal life skills to connect them, including decision-making as a component of creative thinking or value analysis, as well as defining the cognitive content by selecting a relevant content, taking into account the balance between (knowledge, attitudes, skills, and effective teaching methods). That is, skill-based learning does not take place with the interaction of the bodies involved in the educational process. Educationally, training in life skills is significant because of the role played by the human as the educational process focuses on having highly-qualified and efficient human cadres. Hence, education should address the task that fits the aspirations and ambitions of communities (Almahameed and Samreen, 2010).

The author argues that acquiring and educating life skills for disabled students is important. She also appreciates the radical change of the methods and activities of learning, guiding them to enhance these skills, as well as the shift from quantity to quality, and from inflexibility to participation and efficiency.

Furthermore, student activities play an important role in the development of disabled students' life skills. Activity-based learning may be one of the most successful modern teaching methods that help enhance skills, in general, and life skills, in particular, if appropriately designed. These activities transfer knowledge, define attitudes, and form knowledge that affects the learner's behavior in different life situations.

Rashwan and Adel (2009) and Attia (2007) highlight the role of student activities in developing life skills, as follows:

- Activate the role of curriculum and instill concepts, facts, and skills during learning.

- Achieve self-learning and self-confidence.

- Relate to real-life problems.

- Satisfy the tendencies, interests, and needs and consider capabilities.

- Help the learner acquire academic skills, courage, and taking responsibility.

- Promote self-concept and develop thinking and creative solutions to the present and temporary problems.

The author believes that student activities play a significant role in developing the learners' life skills if appropriately designed because they transfer knowledge, define attitudes, and form skills that affect the learner's behavior in the different life situations.

\section{Review of Literature}

\subsection{Studies of student activities:}

Arandes (2017) investigated the relationship between the practice of student activities and educational outcomes among the students of Menoufia University to make mechanisms and action suggestions to enhance the motivation of practicing them, achieving the expected educational outcomes. The study applied a questionnaire to (573) senior students practicing student activities to identify their perspectives on them, achieving the educational outcomes, and the relationship between the practice of their activities and achieving the educational outcomes. It concluded that the practice of student activities among the students of Menoufia University was weak. Furthermore, there were statistically significant differences between the means of the students of Menoufia 
University's practice of student activities according to the nature of the faculty in favor of the theoretical faculties.

Mustafa (2017) aimed to propose a module of human resources in the student activity department, University of Zawia- Libya. The study covered a sample of (180) directors and employees of student activity at the University of Zawia. It utilized an interview form for some staff of the student activity department and affiliated faculties. Results revealed the importance and need for this module among the student activity staff.

Attia (2018) aimed to define the obstacles to the practice of student activities among the students on the university campus. The study also aimed to propose action mechanisms from the perspective of social studies to activate these activities and limit their obstacles. It applied a questionnaire to a randomly selected sample of (360) undergraduate students. It concluded that the practice of student activities has declined lately at the university and campus levels.

Rajab (2017) aimed to measure the impact of practicing student activities on the inclusion of special needs. This study proposed a program to make recommendations that help utilize student activities for the inclusion of the students with special needs more effectively. It highlighted the impact of practicing student activities on the social inclusion of the disabled.

\subsection{Studies of life skills}

Assayed (2007) aimed at investigating the need for life skills according to gender, faculty, academic level, and residency among Israa University students. To achieve its objectives, the study developed and applied a 40-item questionnaire of life skills distributed to (5) domains, i.e. identity, health, social and interpersonal relations, economy and technology, and environment, to a sample of (440) students. It revealed that the students require these needs in a certain order: Health, economy and technology, and social relations, respectively. There were no differences due to gender in all domains, except for social relations. Furthermore, the students at the scientific colleges and residing at the university campus showed higher needs for life skills.

Zareaa (2009) aimed at defining the necessary life skills for the social studies student teacher by applying a proposed training program for developing some life skills in the light of contemporary challenges. Results concluded (14) skills, namely decision-making, reflective thinking, effective communication, time management, scientific research, maintaining property and discipline enforcement, citizenship, teamwork, conflict management, time investment, enjoying trips and organizing vacations, computer skills, and e-learning. The most required skills were computer, elearning, citizenship, and scientific research.

Alwell and Cobb (2009) reviewed life and social skills over the last two decades. Results revealed that most studies reported the importance of life skills curricula in developing social communication skills, enhancing achievement, initiative, volunteer behavior, and competitiveness. Additionally, over $(60 \%)$ of studies did not reveal statistically significant differences in the effectiveness of life skills due to gender. Over $(80 \%)$ of studies stressed adopting the traditional teaching methods was not enough

for forming life skills. Regarding the components of life skills, over (80\%) of studies reported that life skills included three basic parts: The cognitive, skillful, and emotional parts. The most required skills were learning using modern methods, problem-solving skills, as well as emotional and adaptive skills. The social aspect was ranked last.

Algedeby (2010) made a proposal for developing life skills for high school students. The study applied the tools to the social studies teacher students. Results revealed that life skills were taught through subjects, training programs, and manuals. Furthermore, the high school lacked the enrichment of scientific and practical activities for the development of life skills.

Sasila (2011) aimed to investigate the role of the Faculty of Education- Damascus University in achieving life skills derived from the requirements of the attitude towards quality, future school, and academic culture from the students' perspective. The study also examined the difference in achieving these skills among the students according to gender and major. It designed and applied a six-domain 
questionnaire, i.e. identity, social communication, technology, environment, health, and scientific culture, to a sample of (150) students selected from four majors (education, classroom teacher, psychology, and educational and psychological counseling). Results revealed that the achievement of life skills was intermediate, while that of technological and technical skills was low. There were no statistically significant differences in the achievement of life skills according to gender, but there were statistically significant differences according to major in favor of the students of educational and psychological counseling.

Gomez and Marquez (2013) aimed at examining the impact of a training program on students' acquisition of life skills. Results revealed that the experimental group's students had more developmental experiences related to life skills.

Alomarey (2013) aimed at identifying the awareness of the students of the public Jordanian universities of the required life skills in the light of knowledge economy skills. The study covered a sample of (797) students and utilized a 40-item questionnaire distributed to (6) domains representing life skills in the light of knowledge economy principles, i.e. interpersonal communication, negotiation, cooperation and teamwork, decision-making, problem-solving, critical thinking, self-management, emotion management, and stress management. Results revealed that teamwork skills were ranked first. Moreover, there were statistically significant differences in students' responses according to the academic level in favor of the higher levels.

Mahmoud and Mohamed (2014) tackled life skills among university students and their differences according to gender (males- females) and major (humanities-scientific). To achieve its objective, the study designed a scale of life skills depending on the classification of the World Health Organization that consisted of (68) items in the final form. It applied the scale to (748) students at the University of Diyala. Results revealed that the students had a good level of life skills. There was no statistically significant difference between males and females and major (humanities-scientific) in the level of life skills.

\subsection{Studies on both study variables}

Jones and Lavallee (2008) aimed at exploring the impact of a program based on motor and athletic activities in developing some life skills, as well as the ones required for adolescents in Britain. Results showed the effectiveness of the program in developing the proposed life skills. It introduced a set of skills in two fields: Social and personal skills. While the social skills covered respect, leadership, family relations, and communication, the personal ones included self-regulation, setting goals, task management, and motivation. The social skills were more significant.

Bayounis (2016) aimed to investigate the contribution of student activities in the development of students' life skills at King Abdulaziz University from the students' perspective. The study applied a questionnaire to (486) students of King Abdulaziz University in Sulaymaniyah who attended one student activity at least. Results revealed that the students highly needed life skills. The highest ones were memory activation among the students of Science, Engineering, and Computing and Information Technology; application of first aid principles among the students of Arts and Humanities and Law; time management among the students of Home Economics; application of correct eating habits among the students of Communication and Media. Student contribution to the development of life skills was intermediate.

Fayez (2017) aimed to examine the role of recreational camps in developing some life skills among the students of Mansoura University. The study selected a sample of (464) students participating in recreational camps at the university. It concluded that the students of the scientific faculties had higher life skills, objectives, and features than the theoretical ones. Moreover, participation in recreational camps plays an important role in developing life skills among university students. 


\section{Commentary}

1. In terms of topic, the studies of student activities addressed their role, mechanics, forms, as well as acquiring and modifying the behaviors of university students, while the studies of life skills described their reality. Therefore, the present study is one of the first studies on the role of student activities in the development of life skills among disabled students.

2. The studies varied in terms of using the tools. Their analytical and field parts were balanced, but with various and multiple tools.

3. They agreed on the positive effects of student activities, the importance of life skills, and acquiring them in the different stages of education.

4. They agreed that there is a shortage of interest in life skills in teaching.

\section{Methodology}

\subsection{Method}

The study adopted the descriptive survey approach because it addressed the life skills that meet the needs of the disabled students at King Abdulaziz University to define the highest ones. It also investigated the role of student activities in the development of life skills that meet the needs of the disabled students at King Abdulaziz University according to the (type of disability, major, nature of the study, and number of activities) variables.

\subsection{Sampling}

The population covered (92) intentionally selected students with (vision, hearing, motor, and multisensory) impairment and registered in the Deanship of Student Affairs for the Bachelor Degree (Regular and External Study) for the second semester of 2017/2018 at King Abdulaziz University in the majors that they are allowed to join. Table (1) shows the distribution of the participants according to the variables.

Table (1): Distribution of the participants according to the type of disability, major, nature of the study, and number of activities

\begin{tabular}{|l|l|c|c|}
\hline Variable & Number & Percentage \\
\hline \multirow{4}{*}{ Type of disability } & Visual & 40 & $43.5 \%$ \\
\cline { 2 - 4 } & Motor & 29 & $31.5 \%$ \\
\cline { 2 - 4 } & Hearing & 19 & $20.7 \%$ \\
\cline { 2 - 4 } & Multisensory & 4 & $4.3 \%$ \\
\hline \multirow{4}{*}{ Major } & Arts & 51 & $55.4 \%$ \\
\cline { 2 - 4 } & Administration & 30 & $32.6 \%$ \\
\cline { 2 - 4 } & Preparatory Year & 7 & $7.6 \%$ \\
\cline { 2 - 4 } & Media and Communication & 4 & $2.2 \%$ \\
\hline \multirow{3}{*}{ Nature of the study } & Regular & 43 & $46.7 \%$ \\
\cline { 2 - 4 } & External study & 49 & $53.3 \%$ \\
\hline \multirow{3}{*}{ Number of activities } & 5 and more & 32 & $34.8 \%$ \\
\cline { 2 - 4 } & $3-4$ & 20 & $9.8 \%$ \\
\cline { 2 - 4 } & $\mathbf{1 - 2}$ & $\mathbf{2 1 . 7} \%$ \\
\cline { 2 - 4 } & $\mathbf{0}$ & $\mathbf{9 2}$ & $\mathbf{1 0 0} \%$ \\
\hline \multicolumn{2}{|l|}{ Total } & &
\end{tabular}




\subsection{Tools}

The author utilized the following tools:

A. An intake form for the disabled students registered at the Deanship of Student Affairs, King Abdulaziz University: To create the form, the most important information to be collected from the participants was defined. They included the (type of disability, major, nature of the study, and number of activities).

B. Inventory of life skills required for the students of King Abdulaziz University: Bayounis (2016) designed this inventory to define life skills that meet the needs of the students of King Abdulaziz University. It comprised two domains: While domain I focused on the needs of the students for life skills, domain II tackled the contribution of student activities to the development of life skills among the students. They consisted of (28) items each.

The validity of the questionnaire was verified by calculating the values of the Pearson Correlation Coefficient between each item and the total score of the domain. They were all statistically significant at the level of (o.o1), where domain I scored (0.43-0.89) and domain II scored (o.40-0.99), indicating its high validity.

The reliability was verified using Cronbach's alpha and the reliability coefficients scored (o.85o.88) for both domains. The total reliability coefficient scored (o.89). It is a high value.

To test the psychometric characteristics of the questionnaire, it was applied to a sample of (30) disable students to calculate validity and reliability.

\subsection{Validity}

To define the internal validity, the Pearson Correlation Coefficient was calculated between each item and the domain, as shown in table (2).

Table (2): Correlation coefficients between each item and the total score of the domain of the inventory of life skills required for the disabled students at King Abdulaziz University

\begin{tabular}{|c|c|c|c|}
\hline \multicolumn{4}{|c|}{ Domain I } \\
\hline Item & Correlation coefficient & Item & Correlation coefficient \\
\hline 1 & $.70^{\pi}$ & 15 & $.57^{*}$ \\
\hline 2 & $.52^{*}$ & 16 & .62 \\
\hline 3 & $.49^{*}$ & 17 & $.66^{* *}$ \\
\hline 4 & $.53^{*}$ & 18 & $.58^{* *}$ \\
\hline 5 & $.68^{* *}$ & 19 & $.70^{* *}$ \\
\hline 6 & $.76^{*}$ & 20 & $.60^{*+7}$ \\
\hline 7 & .67 & 21 & .53 \\
\hline 8 & $.57^{*+4}$ & 22 & $.58^{* 7}$ \\
\hline 9 & $.62^{* x}$ & 23 & $.82^{x+4}$ \\
\hline 10 & $.71^{* * 4}$ & 24 & $.78^{* *}$ \\
\hline 11 & .74 & 25 & .79 \\
\hline 12 & $.72^{* 4}$ & 26 & $.79^{* 7}$ \\
\hline 13 & $.57^{*}$ & 27 & $.80^{* *+}$ \\
\hline 14 & $.62^{*+1}$ & 28 & $.67^{* x+1}$ \\
\hline \multicolumn{4}{|c|}{ Domain II } \\
\hline Item & Correlation coefficient & Item & Correlation coefficient \\
\hline 1 & .66 & 15 & $.56^{*}$ \\
\hline 2 & $.70^{* x+3}$ & 16 & $.60^{* x+3}$ \\
\hline 3 & $.83^{*}$ & 17 & $.85^{* * x}$ \\
\hline 4 & $.75^{* x+}$ & 18 & $.93^{x+x}$ \\
\hline 5 & $.69^{* * 4}$ & 19 & $.66^{* *}$ \\
\hline
\end{tabular}




\begin{tabular}{|c|l|l|l|}
\hline 6 & $.69^{* *}$ & 20 & $.76^{* *}$ \\
\hline 7 & $.87^{* *}$ & 21 & $.73^{* *}$ \\
\hline 8 & $.84^{* *}$ & 22 & $.83^{* *}$ \\
\hline 9 & $.86^{* *}$ & 23 & $.77^{* *}$ \\
\hline 10 & $.81^{* *}$ & 24 & $.75^{* *}$ \\
\hline 11 & $.86^{* *}$ & 25 & $.81^{* *}$ \\
\hline 12 & $.78^{* * *}$ & 26 & $.84^{* *}$ \\
\hline 13 & $.50^{* *}$ & 27 & $.83^{* *}$ \\
\hline 14 & $.56^{* *}$ & 28 & $.84^{* *}$ \\
\hline
\end{tabular}

** significant at the level of (o.o1)

The table shows that the correlation coefficients between each item and the total score of the questionnaire scored (0.49-0.92) that are significant at the level of (o.o1), indicating its construct validity.

\section{Reliability}

The reliability was estimated by calculating Cronbach's alpha coefficient of the total score, as shown in table (3).

Table (3): Values of Cronbach's alpha coefficient of the inventory of life skills required for the disabled students at King Abdulaziz University

\begin{tabular}{|c|c|c|}
\hline Domain & No. of items & Values of Cronbach's alpha coefficient \\
\hline I & 28 & 0.94 \\
\hline II & 28 & 0.95 \\
\hline Total & 56 & 0.97 \\
\hline
\end{tabular}

Table (3) illustrates that the values of Cronbach's alpha coefficients of the domains scored, (o.94o.95) and the total inventory scored (o.97), indicating the high reliability of the inventory.

The inventory was corrected using the method of Bayounis (2016) to discuss the responses on (5) degrees (very low, below average, average, above average, and very high) to define the extent of the disabled students' needs for life skills and the student activities' contribution to developing life skills from the students' perspective at King Abdulaziz University.

Open-ended questionnaire of student activities (by the author):

It was designed to investigate the student activities offered by the support centers (deanships and faculties) to the disabled students. It included (4) open-ended questions. The first and second questions tackled the domains of the basics of selecting student activities for disabled students and activities. The third and fourth questions covered the nature and type of student activities and life skills to be developed by such student activities.

\section{Results and Discussion}

\subsection{Answer to the first question}

To answer the first question, arithmetic means and standard deviations of the most significant activities that meet the skills and needs of the disabled students at King Abdulaziz University according to the variables, in general, were calculated (Table 4). 
Table (4): Responses of the participants to the items of "to what extent do student activities at King Abdulaziz University contribute to the development of life skills among the disabled students from your perspective?'

\begin{tabular}{|c|c|c|c|c|c|c|c|c|c|c|}
\hline \multirow[b]{2}{*}{ No. } & \multirow[b]{2}{*}{$\begin{array}{l}\text { Standard } \\
\text { deviation }\end{array}$} & \multirow[b]{2}{*}{ Mean } & \multicolumn{5}{|c|}{ Meeting the needs of the disabled students } & \multirow[b]{2}{*}{$\begin{array}{l}\text { Frequency } \\
\text { Percentage }\end{array}$} & \multirow[b]{2}{*}{ Item } & \multirow[b]{2}{*}{ Rank } \\
\hline & & & $\begin{array}{l}\text { Very } \\
\text { low }\end{array}$ & $\begin{array}{l}\text { Below } \\
\text { average }\end{array}$ & Average & $\begin{array}{c}\text { Above } \\
\text { average }\end{array}$ & $\begin{array}{l}\text { Very } \\
\text { high }\end{array}$ & & & \\
\hline \multirow{2}{*}{1} & \multirow{2}{*}{1.01} & \multirow{2}{*}{3.93} & 3 & 1 & 29 & 25 & 34 & Freq. & \multirow{2}{*}{ Problem-solving } & \multirow{2}{*}{1} \\
\hline & & & $3 \cdot 3$ & 1.1 & 31.5 & 27.2 & 37.0 & $\%$ & & \\
\hline \multirow{2}{*}{7} & \multirow{2}{*}{1.09} & \multirow{2}{*}{3.83} & 3 & 4 & 33 & 18 & 34 & Freq. & \multirow{2}{*}{ Planning to achieve goals } & \multirow{2}{*}{2} \\
\hline & & & 3.3 & 4.3 & 35.9 & 19.6 & 37.0 & $\%$ & & \\
\hline & 006 & & o & 5 & 38 & 20 & 29 & Freq. & Self-control & \\
\hline 21 & 0.96 & 3.79 & o & 5.4 & 41.3 & 21.7 & 31.5 & $\%$ & Selr-control & 3 \\
\hline & & & 9 & 27 & o & 29 & 27 & Freq. & & \\
\hline 23 & 1.18 & 3.71 & 9.8 & $29 \cdot 3$ & o & 31.5 & $29 \cdot 3$ & $\%$ & Stress management & 4 \\
\hline & & 268 & 4 & 4 & 34 & 25 & 25 & Freq. & Collecting information & \\
\hline 10 & 1.06 & 3.68 & 4.3 & 4.3 & 37.0 & 27.2 & 27.2 & $\%$ & from different sources & 5 \\
\hline & & 268 & 3 & 6 & 36 & 19 & 28 & Freq. & & 6 \\
\hline 17 & 1.08 & 3.00 & 3.3 & 6.5 & 39.1 & 20.7 & 30.4 & $\%$ & Balancing work and tamily & 6 \\
\hline & 18 & 266 & 6 & 5 & 33 & 18 & 30 & Freq. & Teamwork & \\
\hline 15 & 1.18 & 3.06 & 6.5 & 5.4 & 35.9 & 19.6 & 32.6 & $\%$ & I eamwork & 7 \\
\hline 16 & O & 266 & 3 & 2 & 41 & 23 & 23 & Freq. & Accepting others' & 8 \\
\hline 10 & 0.99 & 3.00 & $3 \cdot 3$ & 2.2 & 44.6 & 25.0 & 25.0 & $\%$ & differences & 0 \\
\hline & & 365 & 9 & o & 34 & 20 & 29 & Freq. & Application of safety and & \\
\hline 24 & 1.21 & 3.05 & 9.8 & o & 37.0 & 21.7 & 31.5 & $\%$ & $\begin{array}{c}\text { security rules inside and } \\
\text { outside the house }\end{array}$ & 9 \\
\hline 8 & 2 & 264 & 7 & o & 37 & 23 & 25 & Freq. & Self-learning & 10 \\
\hline 0 & 1.12 & 3.04 & 7.6 & o & 40.2 & 25.0 & 27.2 & $\%$ & sentiearming & 10 \\
\hline & & & 3 & 2 & 45 & 17 & 25 & Freq. & & \\
\hline 14 & 1.01 & 3.64 & $3 \cdot 3$ & 2.2 & 48.9 & 18.5 & 27.2 & $\%$ & Treatıng children & 11 \\
\hline 22 & 18 & 264 & 8 & 3 & 29 & 26 & 26 & Freq. & Self-ecteem & 2 \\
\hline 22 & 1.18 & 3.64 & 8.7 & 3.3 & 31.5 & 28.3 & 28.3 & $\%$ & Self-esteem & 12 \\
\hline & & & 8 & 2 & 32 & 27 & 23 & Freq. & Time manaroment & \\
\hline 4 & 1.15 & 3.60 & 8.7 & 2.2 & 34.8 & 29.3 & 25.0 & $\%$ & Iime management & 13 \\
\hline 2 & & 258 & 4 & 4 & 42 & 19 & 23 & Freq. & Critical thinking & 4 \\
\hline 2 & 1.05 & 3.58 & 4.3 & 4.3 & $45 \cdot 7$ & 20.7 & 25.0 & $\%$ & Critical thinking & 14 \\
\hline 12 & 16 & & 7 & 4 & 37 & 19 & 25 & Freq. & Listening to the other & 15 \\
\hline 12 & 1.10 & 3.55 & 7.6 & $4 \cdot 3$ & 40.2 & 20.7 & 27.2 & $\%$ & opinion & 15 \\
\hline 6 & 1.28 & & 10 & 4 & 36 & 13 & 29 & Freq. & Establishing personal goals & 16 \\
\hline 6 & 1.28 & $3.5^{1}$ & 10.9 & 4.3 & 39.1 & 14.1 & 31.5 & $\%$ & Establishing personal goals & 16 \\
\hline 11 & 100 & & 3 & 8 & 39 & 25 & 17 & Freq. & Diallog with othere & 17 \\
\hline 11 & 1.00 & 3.49 & $3 \cdot 3$ & 8.7 & 42.4 & 27.2 & 18.5 & $\%$ & Dialog witn otners & 17 \\
\hline & & & 8 & 5 & 38 & 17 & 24 & Freq. & & \\
\hline 26 & 1.19 & 3.48 & 8.7 & 5.4 & 41.3 & 18.5 & 26.1 & $\%$ & Personal hygiene & 18 \\
\hline & & & 7 & 7 & 38 & 15 & 25 & Freq. & Application of correct & \\
\hline 27 & 1.19 & 3.48 & 7.6 & 7.6 & 41.3 & 16.3 & 27.2 & $\%$ & eating habits & 19 \\
\hline 25 & 122 & & 11 & o & 45 & 11 & 25 & Freq. & Application of the first aid & 20 \\
\hline 25 & 1.32 & 3.42 & 12.0 & o & 48.9 & 12.0 & 27.2 & $\%$ & principles & 20 \\
\hline & & & 13 & 2 & 39 & 11 & 27 & Freq. & Creative thinkino & 21 \\
\hline 3 & 1.32 & 3.40 & 14.1 & 2.2 & 42.4 & 12.0 & 29.3 & $\%$ & Creatıve thınkıng & 21 \\
\hline 12 & 152 & & 6 & 3 & 33 & 31 & 17 & Freq. & Self-exprecsion & 20 \\
\hline 13 & $1.5^{2}$ & 3.39 & 6.5 & $3 \cdot 3$ & 35.9 & 33.7 & 18.5 & $\%$ & sentexpression & 22 \\
\hline & & & 10 & 6 & 38 & 16 & 22 & Freq. & Management of financial & \\
\hline 5 & 1.23 & 3.37 & 10.9 & 6.5 & 41.3 & 17.4 & 23.9 & $\%$ & resources & 23 \\
\hline 20 & & & 9 & 7 & 41 & 11 & 24 & Freq. & Wacte recucling & \\
\hline 20 & 1.23 & \begin{tabular}{|c|}
3.37 \\
\end{tabular} & 9.8 & 7.6 & 44.6 & 12.0 & 26.1 & $\%$ & recycling & 24 \\
\hline & & & 7 & 8 & 40 & 19 & 18 & Freq. & & \\
\hline 9 & 1.12 & 3.36 & 7.6 & 8.7 & 43.5 & 20.7 & 19.6 & $\%$ & Memory activation & 25 \\
\hline & & & 9 & 4 & 44 & 15 & 20 & Freq. & Rationalization of & \\
\hline 19 & 1.16 & 3.36 & 9.8 & 4.3 & 47.8 & 16.3 & 21.7 & $\%$ & $\begin{array}{l}\text { consumption of the } \\
\text { available resources }\end{array}$ & 26 \\
\hline
\end{tabular}




\begin{tabular}{|c|c|c|c|c|c|c|c|c|c|c|}
\hline \multirow{2}{*}{28} & \multirow{2}{*}{1.17} & \multirow[b]{2}{*}{3.35} & 10 & 3 & 43 & 17 & 19 & Freq. & \multirow{2}{*}{$\begin{array}{l}\text { Protecting the } \\
\text { environment }\end{array}$} & \multirow{2}{*}{27} \\
\hline & & & 10.9 & 3.3 & 46.7 & 18.5 & 20.7 & $\%$ & & \\
\hline \multirow{3}{*}{18} & \multirow{2}{*}{1.34} & \multirow{2}{*}{3.16} & 17 & 6 & 32 & 19 & 18 & Freq. & \multirow{2}{*}{ Treating children } & \multirow{2}{*}{28} \\
\hline & & & 18.5 & 6.5 & 34.8 & 20.7 & 19.6 & $\%$ & & \\
\hline & \multicolumn{2}{|c|}{3.54} & & & & & & & \multicolumn{2}{|c|}{ Overall mean } \\
\hline
\end{tabular}

Table (4) shows that the overall mean of the skills that meet the needs of the disabled students at King Abdulaziz University was (3.54), indicating that the student activities' contribution to the development of life skills was above average. The participants' responses scored (3.16-3.93) ranging from average to above average. While "problem-solving and decision-making" were ranked the highest, "treating children" was ranked the lowest.

These findings agree with Bayounis (2016), Ibrahim (2019), Jones and Lavallee (2009), and Rajab (2019) reporting the importance of life skills and the role of student activities in their support and enhancing effectiveness. They stress the main idea of the study that student activities promote life skills among the disabled students at King Abdulaziz University, urging for the interest and intensifying them as a means of a more effective social inclusion.

Globally, there is considerable interest in the disabled as an indicator of progress. Because the university is one of the most significant educational institutions in qualifying young men for the leadership and specialized community role, its active contribution in the global community and globalization challenges fits the main purpose of the activities aiming at comprehensive development. The efforts that the university exerts are an important strategic issue with many dimensions and strategies that must receive due attention and prioritizing. Moreover, community service is an integral part of the university's role in all rights and duties towards the various segments of society, including the disabled.

In other words, the success of the university in confronting the problem of the disabled and including them in student activities depends on fulfilling its social role towards them, developing the services related to learning and training, as well as including them in the various social, academic, psychological, and health activities of the society. Consequently, the disabled are included effectively in substantial development. This result stresses the role played by student activities in supporting the life skills of the disabled, especially the females.

The author attributes this result to the significant role of student activities that can be activated in teaching if applied systematically according to the appropriate standards. She argues that the variety and application of student activities give the students the opportunity to cooperate, exchange views, and take responsibility. Furthermore, student activities allow the students ongoing search for and thinking about information. Some topics were raised in the form of problems that require students to choose the appropriate solution.

\subsection{Answer to the second question}

To answer this question, arithmetic means and standard deviations of student activities that meet the skills and needs of the disabled students at King Abdulaziz University according to the (type of disability, major, nature of the study, and number of activities) variables were calculated.

A. The author displays the responses of the disabled students to the items of "the extent to which student activities help develop life skills among the disabled students at King Abdulaziz University according to the type of disability. Table (5) shows the responses of students with (vision, hearing, motor, and multisensory) impairment to the items. 
Table (5): Responses of the participants to the items of "to what extent do student activities contribute to the development of life skills among the disabled students according to the type of disability at King Abdulaziz University?"

\begin{tabular}{|c|c|c|c|c|c|c|c|c|c|c|c|c|c|}
\hline \multirow{2}{*}{ Rank } & \multirow{2}{*}{ Item } & \multicolumn{3}{|c|}{$\begin{array}{l}\text { Type of disability } \\
\text { (vision) } n=40\end{array}$} & \multicolumn{3}{|c|}{$\begin{array}{l}\text { Type of disability } \\
\text { (motor) } n=29\end{array}$} & \multicolumn{3}{|c|}{$\begin{array}{l}\text { Type of disability } \\
\text { (hearing) } n=19\end{array}$} & \multicolumn{3}{|c|}{$\begin{array}{l}\text { Type of disability } \\
\text { (multisensory) } n=4\end{array}$} \\
\hline & & Mean & $\begin{array}{l}\text { Standard } \\
\text { deviation }\end{array}$ & No. & Mean & $\begin{array}{l}\text { Standard } \\
\text { deviation }\end{array}$ & No. & Mean & \begin{tabular}{|l|} 
Standard \\
deviation
\end{tabular} & No. & Mean & $\begin{array}{l}\text { Standard } \\
\text { deviation }\end{array}$ & No. \\
\hline 1 & Problem-solving & 3.95 & 1.01 & 1 & 4.03 & 0.98 & 1 & 3.68 & 1.11 & 1 & 4.25 & 0.96 & 1 \\
\hline 2 & Planning to achieve goals & 3.85 & 1.08 & 7 & 3.90 & 1.11 & 7 & 3.68 & 1.06 & 10 & 4.25 & 0.96 & 5 \\
\hline 3 & Self-control & 3.80 & 0.97 & 21 & 3.83 & 0.97 & 21 & 3.68 & 1.06 & 15 & 4.25 & 0.96 & 7 \\
\hline 4 & Balancing work and family & 3.80 & 1.11 & 23 & 3.76 & 1.06 & 17 & 3.68 & 1.00 & 21 & 4.25 & 0.96 & 12 \\
\hline 5 & Listening to the other opinion & 3.75 & 1.01 & 16 & 3.69 & 1.14 & 12 & 3.63 & 1.07 & 14 & 4.25 & 0.96 & 27 \\
\hline 6 & Accepting others' differences & 3.73 & 1.15 & 8 & 3.69 & 0.97 & 16 & 3.63 & 1.21 & 23 & 4.00 & 0.82 & 2 \\
\hline 7 & Stress management & 3.73 & 1.11 & 10 & 3.69 & 1.23 & 23 & 3.58 & 1.12 & 7 & 4.00 & 0.82 & 6 \\
\hline 8 & $\begin{array}{l}\text { Application of safety and security } \\
\text { rules inside and outside the house }\end{array}$ & 3.73 & 1.24 & 15 & 3.69 & 1.26 & 24 & 3.53 & 1.17 & 8 & 4.00 & 0.82 & 9 \\
\hline 9 & $\begin{array}{l}\text { Collecting information from different } \\
\text { sources }\end{array}$ & 3.73 & 1.09 & 17 & 3.66 & 1.08 & 10 & 3,47 & 1.02 & 2 & 4.00 & 0.82 & 17 \\
\hline 10 & Treating children & 3.73 & 1.11 & 4 & 3.66 & 0.94 & 14 & 3,47 & 1.12 & 4 & 4.00 & 0.82 & 19 \\
\hline 11 & Self-esteem & 3.73 & 1.20 & 22 & 3.66 & 1.14 & 22 & 3,47 & 1.07 & 16 & 4.00 & 0.82 & 20 \\
\hline 12 & Self-learning & 3.68 & 1.23 & 24 & 3.62 & 1.12 & 8 & 3,47 & 1.35 & 22 & 4.00 & 0.82 & 21 \\
\hline 13 & Teamwork & 3.63 & 1.05 & 13 & 3.59 & 1.21 & 15 & 3,47 & 1.22 & 24 & 4.00 & 0.82 & 24 \\
\hline 14 & Application of correct eating habits & 3.63 & 1.08 & 14 & 3.59 & 1.15 & 27 & 3,42 & 1.12 & 13 & 3.75 & 0.96 & 3 \\
\hline 15 & Critical thinking & 3.63 & 1.11 & 2 & 3.55 & 1.06 & 2 & 3,42 & 1.17 & 17 & 3.75 & 0.96 & 14 \\
\hline 16 & Time management & 3.58 & 1.13 & 6 & 3.55 & 1.24 & 4 & 3.37 & 1.07 & 11 & 3.75 & 0.50 & 22 \\
\hline 17 & Personal hygiene & 3.58 & 1.13 & 26 & 3.55 & 1.21 & 26 & 3.32 & 1.20 & 12 & 3.75 & 0.96 & 25 \\
\hline 18 & Establishing personal goals & 3.55 & 1.04 & 11 & $3 \cdot 52$ & 1.33 & 6 & 3.32 & 1.25 & 20 & 3.75 & 0.96 & 28 \\
\hline 19 & Application of the first aid principles & 3.55 & 1.18 & 12 & $3 \cdot 52$ & 1.24 & 25 & 3.26 & 1.28 & 6 & 3.50 & 1.29 & 4 \\
\hline 20 & Dialog with others & 3.45 & 1.38 & 3 & 3.48 & 0.99 & 11 & 3.26 & 1.10 & 9 & 3.50 & 0.58 & 8 \\
\hline 21 & Creative thinking & 3.43 & 1.26 & 25 & 3.45 & 1.33 & 3 & 3.26 & 1.19 & 19 & 3.50 & 0.58 & 10 \\
\hline 22 & Protecting the environment & 3.43 & 1.20 & 27 & 3.45 & 1.21 & 28 & 3.26 & 1. 28 & 27 & 3.50 & 0.58 & 11 \\
\hline 23 & $\begin{array}{l}\text { Rationalization of consumption of the } \\
\text { available resources }\end{array}$ & 3.43 & 1.24 & 5 & 3.41 & 1.21 & 19 & 3.21 & 1.27 & 25 & 3.50 & $0.5^{8}$ & 15 \\
\hline 24 & Waste recycling & 3.35 & 1.17 & 28 & 3.41 & 1.27 & 20 & 3.21 & 1.23 & 26 & 3.50 & 0.58 & 16 \\
\hline 25 & Memory activation & 3.33 & 1.14 & 9 & 3.38 & 1.18 & 9 & 3.16 & 1.30 & 3 & 3.50 & 0.58 & 18 \\
\hline 26 & Management of financial resources & 3.33 & 1.16 & 19 & 3.34 & 1.23 & 5 & 3.16 & 1.26 & 5 & 3.25 & 1.71 & 23 \\
\hline 27 & Self-expression & 3.33 & 1.24 & 20 & 3.28 & 1.75 & 13 & 3.11 & 1.20 & 28 & 3.25 & 1.71 & 26 \\
\hline 28 & Treating children & 3.23 & 1.37 & 18 & 3.21 & 1.29 & 18 & 2.89 & 1.50 & 18 & 3.25 & 175 & 13 \\
\hline \multicolumn{2}{|c|}{ Overall mean } & \multicolumn{3}{|c|}{3.58} & \multicolumn{3}{|c|}{3.57} & \multicolumn{3}{|c|}{3.39} & \multicolumn{3}{|c|}{3.74} \\
\hline
\end{tabular}

Table (5) shows that the overall mean of the skills that meet the students with vision impairment at King Abdulaziz University was (3.58), suggesting that student activities' contribution to the development of life skills was "above average". The participants' responses scored (3.23-3.95), ranging from "average" to "above average". While "problem-solving and decision-making" were ranked the highest, "treating children" was ranked the lowest.

This finding highlights the role and contribution of activities in the development of life skills among students with vision impairment. They ranked "problem-solving and decision-making" the highest skills because they are more likely to help live a natural life. These skills, especially for the disabled, are important issues that create a sense of practicing life activities like their healthy peers.

The table also shows that the overall mean of the skills that meet the students with motor impairment at King Abdulaziz University was (3.57), suggesting that student activities' contribution to the development of life skills was "above average". The participants' responses scored (3.21-4.03), ranging from "average" to "above average". While "problem-solving and decision-making" were ranked the highest, "treating children" was ranked the lowest.

The arithmetic mean emphasized the role of activities in supporting the life skills of the students with motor impairment at King Abdulaziz University. This result agrees with the previous table that "problem-solving and decision making" are the most important skills developed because of activities. Furthermore, the students with motor and hearing impairment ranked "treating children" the lowest because some of them are single and that this skill required more than student activities. It requires a deeper study and refinement. 
In addition, the overall mean of the skills that meet the students with hearing impairment at King Abdulaziz University was (3.39), suggesting that student activities' contribution to the development of life skills was "above average". The participants' responses scored (2.89-3.86), ranging from "average" to "above average". While "problem-solving and decision-making" were ranked the highest, "treating children" was ranked the lowest. This result matches the two previous tables.

The overall mean of the skills that meet the students with multisensory impairment at King Abdulaziz University was (3.47), suggesting that student activities' contribution to the development of life skills was "above average". The participants' responses scored (3.86-4.25), ranging from "average" to "above average". While "problem-solving and decision-making" were ranked the highest, "self-expression" was ranked the lowest.

The students with multisensory impairment agree with the other participants that the most significant skills that could be developed by student activities are "problem-solving and decisionmaking". However, they believe that the lowest skill is "self-expression" because their disability is higher and self-expression needs more effort.

B. The author displays the responses of the disabled students to the items of "the extent to which student activities help develop life skills among the disabled students at King Abdulaziz University according to major, as shown in table (6).

Table (6): Responses of the participants to the items of "to what extent do student activities contribute to the development of life skills among the disabled students at King Abdulaziz University according to major?'

\begin{tabular}{|c|c|c|c|c|c|c|c|c|c|c|c|c|c|}
\hline \multirow[t]{2}{*}{ Rank } & \multirow[t]{2}{*}{ Item } & \multicolumn{3}{|c|}{$\begin{array}{l}\text { Economics and } \\
\text { Administration } \\
\qquad n=30\end{array}$} & \multicolumn{3}{|c|}{$\begin{array}{c}\text { Arts and } \\
\text { Humanities } \\
n=51\end{array}$} & \multicolumn{3}{|c|}{$\begin{array}{l}\text { Communication, } \\
\text { Media,Design, } \\
\text { and Arts } n=4\end{array}$} & \multicolumn{3}{|c|}{$\begin{array}{l}\text { Preparatory } \\
\text { Year } n=7\end{array}$} \\
\hline & & Mean & \begin{tabular}{l|} 
Standard \\
deviation
\end{tabular} & No. & Mean & $\begin{array}{l}\text { Standard } \\
\text { deviation }\end{array}$ & No. & Mean & $\begin{array}{l}\text { Standard } \\
\text { deviation }\end{array}$ & No. & Mean & $\begin{array}{l}\text { Standard } \\
\text { deviation }\end{array}$ & No. \\
\hline 1 & Problem-solving & 3.90 & 1.09 & 7 & 4.06 & 0.88 & 1 & 4.06 & 0.88 & 1 & 4.14 & 0.9 & 1 \\
\hline 2 & Planning to achieve goals & 3.87 & 1.28 & 24 & 4.04 & 0.92 & 7 & 4.04 & 0.92 & 7 & 3.86 & 1.07 & 14 \\
\hline 3 & Self-control & 3.83 & 0.95 & 10 & 4.02 & 0.91 & 23 & 4.02 & 0.91 & 23 & 3.43 & 0.79 & 21 \\
\hline 4 & Balancing work and family & 3.80 & 1.24 & 4 & 3.96 & 0.92 & 21 & 3.96 & 0.92 & 21 & 3.29 & 0.49 & 2 \\
\hline 5 & Listening to the other opinion & 3.80 & 1.03 & 12 & 3.94 & 1.01 & 15 & 3.94 & 1.01 & 15 & 2.14 & 1.07 & 3 \\
\hline 6 & Accepting others' differences & 3.80 & 1.24 & 13 & 3.92 & 1.02 & 22 & 3.92 & 1.02 & 22 & 2.14 & 1.07 & 4 \\
\hline 7 & Stress management & 3.73 & 1.26 & 1 & 3.90 & 0.88 & 16 & 3.90 & 0.88 & 16 & 2.14 & 1.07 & 5 \\
\hline 8 & $\begin{array}{l}\text { Application of safety and security rules inside and outside the } \\
\text { house }\end{array}$ & 3.73 & 1.01 & 20 & 3.90 & 0.94 & 17 & 3.90 & 0.94 & 17 & 2.14 & 1.07 & 6 \\
\hline 9 & Collecting information from different sources & 3.63 & 1.10 & 5 & 3.86 & 0.96 & 8 & 3.86 & 0.96 & 8 & 2.14 & 1.07 & 7 \\
\hline 10 & Treating children & 3.63 & 1.19 & 8 & 3.86 & 0.94 & 10 & 3.86 & 0.94 & 10 & 2.14 & 1.07 & 8 \\
\hline 11 & Self-esteem & 3.63 & 0.89 & 16 & 3.73 & 0.87 & 11 & 3.73 & 0.87 & 11 & 2.14 & 1.07 & 9 \\
\hline 12 & Self-learning & 3.63 & 1.10 & 17 & 3.71 & 1.10 & 24 & 3.71 & 1.10 & 24 & 2.14 & 1.07 & 10 \\
\hline 13 & Teamwork & 3.60 & 1.25 & 2 & 3.71 & 0.97 & 26 & 3.71 & 0.97 & 26 & 2.14 & 1.07 & 11 \\
\hline 14 & Application of correct eating habits & 3.60 & 1.33 & 3 & 3.69 & 1.01 & 4 & 3.69 & 1.01 & 4 & 2.14 & 1.07 & 12 \\
\hline 15 & Critical thinking & 3.60 & 1.25 & 6 & 3.65 & 1.28 & 6 & 3.65 & 1.28 & 6 & 2.14 & 1.07 & 13 \\
\hline 16 & Time management & 3.60 & 1.22 & 9 & 3.65 & 0.98 & 14 & 3.65 & 0.98 & 14 & 2.14 & 1.07 & 15 \\
\hline 17 & Personal hygiene & 3.60 & 1.13 & 14 & 3.61 & 1.02 & 2 & 3.61 & 1.02 & 2 & 2.14 & 1.07 & 16 \\
\hline 18 & Establishing personal goals & 3.60 & 1.33 & 27 & 3.61 & 1.17 & 12 & 3.61 & 1.17 & 12 & 2.14 & 1.07 & 17 \\
\hline 19 & Application of the first aid principles & 3.57 & 1.28 & 15 & $3 \cdot 57$ & 1.08 & 25 & 3.57 & 1.08 & 25 & 2.14 & 1.07 & 18 \\
\hline 20 & Dialog with others & 3.57 & 1.07 & 21 & 3.55 & 1.22 & 18 & 3.55 & 1.22 & 18 & 2.14 & 1.07 & 19 \\
\hline 21 & Creative thinking & 3.53 & 1.28 & 22 & 3.55 & 1.06 & 27 & 3.55 & 1.06 & 27 & 2.14 & 1.07 & 20 \\
\hline 22 & Protecting the environment & 3.53 & 1.20 & 28 & 3.45 & 1.32 & 3 & 3.45 & 1.32 & 3 & 2.14 & 1.07 & 22 \\
\hline 23 & Rationalization of consumption of the available resources & 3.50 & 1.38 & 23 & 3.45 & 1.14 & 19 & 3.45 & 1.14 & 19 & 2.14 & 1.07 & 23 \\
\hline 24 & Waste recycling & 3.47 & 1.17 & 19 & 3.41 & 1.25 & 5 & 3.41 & 1.25 & 5 & 2.14 & 1.07 & 24 \\
\hline 25 & Memory activation & 3.47 & 1.43 & 25 & 3.39 & 1.13 & 28 & $3 \cdot 39$ & 1.13 & 28 & 2.14 & 1.07 & 25 \\
\hline 26 & Management of financial resources & 3.40 & 1.00 & 11 & 3.37 & 1.02 & 9 & 3.37 & 1.02 & 9 & 2.14 & 1.07 & 26 \\
\hline 27 & Self-expression & 3.33 & 1.42 & 26 & 3.35 & 1.66 & 13 & 3.35 & 1.66 & 13 & 2.14 & 1.07 & 27 \\
\hline 28 & Treating children & 2.83 & 1.34 & 18 & $3 \cdot 31$ & 1.30 & 20 & 3.31 & 1.30 & 20 & 2.14 & 1.07 & 28 \\
\hline \multicolumn{2}{|c|}{ Overall mean } & \multicolumn{3}{|c|}{3.59} & \multicolumn{3}{|c|}{3.68} & \multicolumn{3}{|c|}{3.65} & \multicolumn{3}{|c|}{2.63} \\
\hline
\end{tabular}

Table (6) shows that the overall mean of the skills that meet the needs of the disabled students (major: Economics and Administration) at King Abdulaziz University was (3.59), indicating that the student activities' contribution to the development of life skills was above average. The participants' 
responses scored (2.82-3.90) ranging from average to above average. While "planning to achieve goals" was ranked the highest, "treating children" was ranked the lowest.

Thus, the role of student activities in developing life skills among the disabled students according to major (Economics and Administration) was "planning to achieve goals". It is a logical and realistic result because of the nature of this major.

The overall mean of the skills that meet the needs of the disabled students (major: Arts and Humanities) at King Abdulaziz University was (3.68), indicating that the student activities' contribution to the development of life skills was above average. The participants' responses scored (3.31-4.06) ranging from average to above average. While "problem-solving" was ranked the highest, "treating children" was ranked the lowest. It shows the role of student activities in supporting human activities among those students who ranked "problem-solving" the highest.

The overall mean of the skills that meet the needs of the disabled students (major: Media, Communication, and Arts) at King Abdulaziz University was (3.65), indicating that the student activities' contribution to the development of life skills was above average. The participants' responses scored (3.31-4.02) ranging from average to above average. While "stress management" was ranked the highest, "waste recycling" was ranked the lowest. Those students ranked "stress management" the highest life skills developed by the activities. It is a natural result given their major because they need emotional stability and good conduct under pressure.

The overall mean of the skills that meet the needs of the disabled students (major: Preparatory Year) at King Abdulaziz University was (2.63), indicating that the student activities' contribution to the development of life skills was above average. The participants' responses scored (2.14-4.14) ranging from average to below average. While "stress management" was ranked the highest, "problem-solving and protecting the environment" skills were ranked the lowest. This result matches the results of the previous table that stress management is the highest skill to be developed by student activities.

C. The author displays the responses of the disabled students to the items of "the extent to which student activities help develop life skills among the disabled students at King Abdulaziz University according to nature of the study (Regular and External Study), as shown in table (7).

Table (7): Responses of the participants to the items of "to what extent do student activities at King Abdulaziz University contribute to the development of life skills among the disabled students according to nature of the study (Regular and External Study)?"

\begin{tabular}{|c|l|c|c|c|c|c|c|}
\hline \multirow{2}{*}{ Rank } & \multirow{2}{*}{} & \multicolumn{3}{|c|}{ Regular $\mathrm{n}=43$} & \multicolumn{3}{c|}{ External Study $\mathrm{n}=49$} \\
\cline { 3 - 8 } & & Mean & $\begin{array}{c}\text { Standard } \\
\text { deviation }\end{array}$ & No. & Mean & $\begin{array}{c}\text { Standard } \\
\text { deviation }\end{array}$ & No. \\
\hline 1 & Problem-solving & 3.93 & 0.96 & 1 & 3.94 & 1.07 & 1 \\
\hline 2 & Self-control & 3.91 & 1.06 & 7 & 3.90 & 0.94 & 21 \\
\hline 3 & Stress management & 3.97 & 1.01 & 17 & 3.82 & 1.29 & 23 \\
\hline 4 & llanning to achieve goals & 3.77 & 0.95 & 16 & 3.76 & 1.11 & 7 \\
\hline 5 & Self-esteem & 3.74 & 1.05 & 10 & 3.73 & 1.20 & 22 \\
\hline 6 & lritical thinking & 3.70 & 1.06 & 8 & 3.69 & 1.10 & 2 \\
\hline 7 & leamwork & 3.70 & 1.23 & 24 & 3.69 & 1.16 & 15 \\
\hline 8 & lreating children & 3.67 & 0.97 & 21 & 3.65 & 1.09 & 14 \\
\hline 9 & Collecting information from different sources & 3.65 & 1.09 & 4 & 3.63 & 1.07 & 10 \\
\hline 10 & Application of safety and security rules inside and & 3.63 & 1.00 & 13 & 3.61 & 1.20 & 24 \\
\hline 11 & Seutside the house & 3.63 & 0.93 & 14 & 3.59 & 1.17 & 8 \\
\hline 12 & Balancing work and family & 3.63 & 1.22 & 15 & 3.59 & 1.14 & 17 \\
\hline 13 & Accepting others' differences & 3.60 & 1.14 & 12 & 3.57 & 1.02 & 16 \\
\hline 14 & Time management & 3.58 & 1.05 & 23 & 3.55 & 1.21 & 4 \\
\hline 15 & Listening to the other opinion & 3.58 & 1.10 & 26 & 3.51 & 1.19 & 12 \\
\hline
\end{tabular}




\begin{tabular}{|c|l|c|c|c|c|c|c|}
\hline \multirow{2}{*}{ Rank } & \multirow{2}{*}{} & \multicolumn{3}{|c|}{ Regular $\mathrm{n}=43$} & \multicolumn{3}{c|}{ External Study $\mathrm{n}=49$} \\
\cline { 3 - 8 } & & Mean & $\begin{array}{c}\text { Standard } \\
\text { deviation }\end{array}$ & No. & Mean & $\begin{array}{c}\text { Standard } \\
\text { deviation }\end{array}$ & No. \\
\hline 16 & Establishing personal goals & 3.53 & 1.26 & 6 & 3.49 & 1.31 & 6 \\
\hline 17 & Dialog with others & 3.53 & 1.16 & 22 & 3.47 & 1.04 & 11 \\
\hline 18 & Application of correct eating habits & 3.53 & 1.12 & 27 & 3.43 & 1.26 & 27 \\
\hline 19 & Protecting the environment & 3.51 & 0.96 & 11 & 3.41 & 1.21 & 28 \\
\hline 20 & Application of the first aid principles & 3.47 & 1.24 & 3 & 3.39 & 1.29 & 25 \\
\hline 21 & Personal hygiene & 3.47 & 1.18 & 25 & 3.39 & 1.27 & 26 \\
\hline 22 & Management of financial resources & 3.44 & 0.98 & 2 & 3.37 & 1.30 & 5 \\
\hline 23 & Memory activation & 3.42 & 1.14 & 20 & 3.37 & 1.22 & 9 \\
\hline 24 & Creative thinking & 3.40 & 1.05 & 19 & 3.35 & 1.39 & 3 \\
\hline 25 & $\begin{array}{l}\text { Rationalization of consumption of the available } \\
\text { resources }\end{array}$ & 3.37 & 1.16 & 5 & 3.33 & 1.26 & 19 \\
\hline 26 & Waste recycling & 3.35 & 1.02 & 9 & 3.33 & 1.31 & 20 \\
\hline 27 & Self-expression & 3.28 & 1.14 & 28 & 3.18 & 1.84 & 13 \\
\hline 28 & Treating children & 3.26 & 1.26 & 18 & 3.08 & 1.41 & 18 \\
\hline Overall mean & & 3.57 & & & 3.52 & \\
\hline
\end{tabular}

Table (7) shows that the overall mean of the skills that meet the needs of the regular disabled students at King Abdulaziz University was (3.57), indicating that the student activities' contribution to the development of life skills was above average. The participants' responses scored (3.26-3.94) ranging from average to above average. While "problem-solving" was ranked the highest, "treating children" was ranked the lowest. Both groups ranked problem-solving as the highest skill developed by student activities.

The overall mean of the skills that meet the needs of the external study disabled students at King Abdulaziz University was (3.52), indicating that the student activities' contribution to the development of life skills was above average. The participants' responses scored (3.08-3.94) ranging from average to above average. While "problem-solving" was ranked the highest, "treating children" was ranked the lowest.

D. The author displays the responses of the disabled students to the items of "the extent to which student activities help develop life skills among the disabled students at King Abdulaziz University according to the number of activities, as shown in table (8).

Table (8): Responses of the participants to the items of "to what extent do student activities contribute to the development of life skills among the disabled students according to the number of activities at King Abdulaziz University?"

\begin{tabular}{|c|c|c|c|c|c|c|c|c|c|c|c|c|c|}
\hline \multirow{2}{*}{ Rank } & \multirow{2}{*}{ Item } & \multicolumn{3}{|c|}{$\begin{array}{c}0 \\
\mathrm{n}=31\end{array}$} & \multicolumn{3}{|c|}{$\begin{array}{c}1-2 \\
n=20\end{array}$} & \multicolumn{3}{|c|}{$\begin{array}{l}3-4 \\
n=9\end{array}$} & \multicolumn{3}{|c|}{$\begin{array}{c}5 \text { and more } \\
n=32\end{array}$} \\
\hline & & Mean & $\begin{array}{l}\text { Standard } \\
\text { deviation }\end{array}$ & No. & Mean & $\begin{array}{l}\text { Standard } \\
\text { deviation }\end{array}$ & No. & Mean & $\begin{array}{l}\text { Standard } \\
\text { deviation }\end{array}$ & No. & Mean & $\begin{array}{l}\text { Standard } \\
\text { deviation }\end{array}$ & No. \\
\hline 1 & Problem-solving & 3.97 & 0.95 & 1 & 4.20 & 0.95 & 7 & 4.11 & 0.93 & 1 & 3.84 & 1.17 & 22 \\
\hline 2 & Planning to achieve goals & 3.74 & 1.18 & 7 & 4.00 & 0.92 & 1 & 4.11 & 0.93 & 21 & 3.81 & 1.18 & 1 \\
\hline 3 & Self-control & 3.68 & 1.35 & 15 & 4.00 & 0.92 & 12 & 3.89 & 1.27 & 23 & 3.78 & 0.94 & 10 \\
\hline 4 & Balancing work and family & 3.65 & 1.23 & 8 & 4.00 & 0.92 & 17 & 3.78 & 1.30 & 14 & 3.78 & 0.97 & 21 \\
\hline 5 & Listening to the other opinion & 3.65 & 1.14 & 16 & 4.00 & 0.86 & 22 & 3.67 & 0.71 & 2 & 3.57 & 1.16 & 6 \\
\hline 6 & Accepting others' differences & 3.65 & 0.98 & 21 & 4.00 & 0.92 & 24 & 3.67 & 1.22 & 24 & 3.75 & 1.02 & 7 \\
\hline 7 & Stress management & 3.61 & 1.12 & 23 & 3.90 & 0.85 & 16 & 3.56 & 1.24 & 7 & 3.69 & 1.15 & 15 \\
\hline 8 & $\begin{array}{l}\text { Application of safety and security rules inside } \\
\text { and outside the house }\end{array}$ & $3 \cdot 55$ & 1.31 & 4 & 3.90 & 0.91 & 21 & 3.56 & 1.13 & 8 & 3.69 & 1.00 & 17 \\
\hline 9 & Collecting information from different sources & 3.55 & 1.18 & 10 & 3.90 & 1.07 & 23 & 3.56 & 1.24 & 10 & 3.66 & 0.83 & 16 \\
\hline 10 & Treating children & 3.55 & 1.03 & 14 & 3.90 & 0.97 & 27 & 3.56 & 1.42 & 17 & 3.63 & 1.31 & 23 \\
\hline 11 & Self-esteem & 3.52 & 1.03 & 2 & 3.85 & 1.14 & 6 & 3.56 & 1.24 & 20 & 3.59 & 1.21 & 24 \\
\hline 12 & Self-learning & 3.52 & 1.18 & 13 & 3.85 & 0.88 & 8 & 3.56 & 1.24 & 28 & 3.56 & 1.11 & 4 \\
\hline
\end{tabular}




\begin{tabular}{|c|c|c|c|c|c|c|c|c|c|c|c|c|c|}
\hline \multirow{2}{*}{ Rank } & \multirow{2}{*}{ Item } & \multicolumn{3}{|c|}{$\begin{array}{c}0 \\
n=31\end{array}$} & \multicolumn{3}{|c|}{$\begin{array}{c}1-2 \\
n=20\end{array}$} & \multicolumn{3}{|c|}{$\begin{array}{l}3-4 \\
n=9\end{array}$} & \multicolumn{3}{|c|}{$\begin{array}{c}5 \text { and more } \\
\mathrm{n}=32\end{array}$} \\
\hline & & Mean & \begin{tabular}{|l|}
$\begin{array}{l}\text { Standard } \\
\text { deviation }\end{array}$ \\
\end{tabular} & No. & Mean & $\begin{array}{l}\text { Standard } \\
\text { deviation }\end{array}$ & No. & Mean & \begin{tabular}{|l|} 
Standard \\
deviation \\
\end{tabular} & No. & Mean & $\begin{array}{l}\text { Standard } \\
\text { deviation }\end{array}$ & No. \\
\hline 13 & Teamwork & 3.52 & 1.15 & 17 & 3.85 & 0.93 & 14 & 3.44 & 1.24 & 4 & 3.56 & 0.98 & 14 \\
\hline 14 & Application of correct eating habits & 3.48 & 1.36 & 24 & 3.85 & 0.99 & 25 & 3.44 & 1.24 & 9 & 3.53 & 1.27 & 2 \\
\hline 15 & Critical thinking & 3.45 & 1.18 & 12 & 3.80 & 0.95 & 4 & 3.44 & 1.33 & 19 & 3.53 & 1.08 & 5 \\
\hline 16 & Time management & 3.39 & 1.17 & 11 & 3.80 & 1.01 & 10 & 3.44 & 1.51 & 27 & 3.53 & 1.16 & 8 \\
\hline 17 & Personal hygiene & 3.39 & 1.17 & 26 & 3.80 & 1.15 & 26 & 3.33 & 1.41 & 5 & 3.53 & 0.92 & 11 \\
\hline 18 & Establishing personal goals & $3 \cdot 32$ & 1.19 & 27 & 3.75 & 1.16 & 3 & 3.33 & 1.22 & 15 & 3.50 & 1.41 & 3 \\
\hline 19 & Application of the first aid principles & 3.39 & 1.24 & 22 & 3.75 & 0.97 & 9 & 3.33 & 1.41 & 22 & 3.50 & 1.14 & 12 \\
\hline 20 & Dialog with others & 3.39 & 1.38 & 20 & 3.75 & 0.97 & 15 & 3.33 & 1.50 & 25 & 3.47 & 0.98 & 13 \\
\hline 21 & Creative thinking & 3.23 & 1.38 & 25 & 3.70 & 0.86 & 2 & 3.33 & 1.41 & 26 & 3.44 & 1.13 & 18 \\
\hline 22 & Protecting the environment & 3.23 & 1.15 & 28 & 3.70 & 0.80 & 11 & 3.22 & 1.20 & 3 & 3.41 & 1.07 & 09 \\
\hline 23 & $\begin{array}{l}\text { Rationalization of consumption of the } \\
\text { available resources }\end{array}$ & 3.19 & 1.28 & 19 & 3.60 & 1.10 & 28 & 3.22 & 1.39 & 6 & 3.41 & 1.19 & 26 \\
\hline 24 & Waste recycling & 3.16 & 1.13 & 9 & 3.55 & 1.15 & 20 & 3.22 & 1.09 & 11 & 3.38 & 1.13 & 25 \\
\hline 25 & Memory activation & 3.13 & 1.34 & 3 & 3.50 & 1.19 & 5 & 3.22 & 1.20 & 16 & 3.38 & 1.21 & 27 \\
\hline 26 & Management of financial resources & 3.13 & 1.36 & 5 & 3.50 & 1.10 & 19 & 3.11 & 1.54 & 12 & 3.34 & 1.15 & 20 \\
\hline 27 & Self-expression & 3.13 & 1.38 & 6 & 3.35 & 1.93 & 13 & 2.78 & 2.82 & 13 & 3.28 & 1.17 & 9 \\
\hline 28 & Treating children & 2.97 & 1.45 & 18 & 3.25 & 1.29 & 18 & 2.64 & 1.66 & 18 & 3.25 & 1.24 & 28 \\
\hline \multicolumn{2}{|c|}{ Overall mean } & \multicolumn{3}{|c|}{3.42} & \multicolumn{3}{|c|}{3.78} & \multicolumn{3}{|c|}{3.44} & \multicolumn{3}{|c|}{3.56} \\
\hline
\end{tabular}

Table (8) shows that the overall mean of the skills that meet the needs of the disabled students at King Abdulaziz University was (3.42), indicating that the student activities' contribution to the development of life skills was above average. The participants' responses scored (2.97-3.97) ranging from average to above average. While "problem-solving" was ranked the highest, "treating children" was ranked the lowest.

The overall mean of the skills that meet the needs of the disabled students who attended (1-2) activities at King Abdulaziz University was (3.42), suggesting that student activities' contribution to the development of life skills was above average. The participants' responses scored (3.25-4.20) ranging from average to above average. While "planning to achieve goals" was ranked the highest, "treating children" was ranked the lowest.

The overall mean of the skills that meet the needs of the disabled students who attended (3-4) activities at King Abdulaziz University was (3.44), suggesting that student activities' contribution to the development of life skills was above average. The participants' responses scored (2.67-4.11) ranging from average to above average. While "problem-solving" was ranked the highest, "treating children" was ranked the lowest.

The overall mean of the skills that meet the needs of the disabled students who attended ( 5 and more) activities at King Abdulaziz University was (3.56), suggesting that student activities' contribution to the development of life skills was above average. The participants' responses scored (3.25-3.84) ranging from average to above average. While "self-esteem" was ranked the highest, "protecting the environment" was ranked the lowest.

The results of the table illustrate that the disabled students, with the different activities they did, stressed the role of student activities in developing the various life skills. They ranked "problemsolving, planning to achieve goals, and self-esteem" the highest skills, suggesting their important role. In other words, these high skills highlight the prominent role of student activities as a practice and positive behavior that help enhance the inclusion rates of this category in the university community and society, in general. This result agrees with Jones and Lavallee (2009).

\subsection{Answer to the third question}

To answer this question, the author calculated the arithmetic means and standard deviations of the skills showing the need of the participants for each skill in the inventory of the life skills required for the disabled students at King Abdulaziz University (table 9). 
Table (9): Responses of the participants to the items of the extent of the required life skills for the disabled students

\begin{tabular}{|c|c|c|c|c|c|c|c|c|c|c|}
\hline \multirow{2}{*}{ Rank } & \multirow{2}{*}{$\begin{array}{l}\text { Standard } \\
\text { deviation }\end{array}$} & \multirow{2}{*}{ Mean } & \multicolumn{5}{|c|}{$\begin{array}{l}\text { Meeting the needs of the } \\
\text { disabled students }\end{array}$} & \multirow{2}{*}{$\begin{array}{c}\text { Frequency } \\
\text { and } \\
\text { Percentage }\end{array}$} & \multirow{2}{*}{ Item } & \multirow{2}{*}{ No. } \\
\hline & & & $\begin{array}{l}\text { Very } \\
\text { low }\end{array}$ & $\begin{array}{c}\text { Below } \\
\text { average }\end{array}$ & Average & $\begin{array}{c}\text { Above } \\
\text { average }\end{array}$ & $\begin{array}{l}\text { Very } \\
\text { high }\end{array}$ & & & \\
\hline \multirow{2}{*}{25} & \multirow{2}{*}{1.13} & \multirow{2}{*}{4.17} & 4 & 5 & 12 & 21 & 50 & Freq. & \multirow{2}{*}{ Application of the first aid principles } & \multirow{2}{*}{1} \\
\hline & & & $4 \cdot 3$ & 5.4 & 13.0 & 22.8 & $54 \cdot 3$ & $\%$ & & \\
\hline \multirow{2}{*}{3} & \multirow{2}{*}{1.01} & 16 & 2 & 3 & 19 & 22 & 46 & Freq. & Creative thinking & 2 \\
\hline & & 4.10 & 2.2 & $3 \cdot 3$ & 20.7 & 23.9 & 50.0 & $\%$ & creduve tminkmg & 2 \\
\hline & & & & 10 & 21 & 13 & 48 & Freq. & Stress management & \\
\hline 23 & 1.09 & 4.08 & & 10.9 & 22.8 & 14.1 & 52.2 & $\%$ & stress management & 3 \\
\hline 24 & 10 & 8 & 2 & 11 & 16 & 12 & 51 & Freq. & Application of safety and security rules & \\
\hline 24 & 1.19 & 4.00 & 2.2 & 12.0 & 17.4 & 13.0 & 55.4 & $\%$ & inside and outside the house & 4 \\
\hline & & & 2 & 10 & 20 & 14 & 46 & Freq. & & \\
\hline 26 & 1.17 & 4.00 & 2.2 & 10.9 & 21.7 & 15.2 & 50.5 & $\%$ & Personal hygiene & 5 \\
\hline 1 & 208 & 20 & 5 & 6 & 18 & 20 & 43 & Freq. & Self control & 6 \\
\hline 21 & 3.90 & 1.20 & 5.4 & 6.5 & 19.6 & 21.7 & 46.7 & $\%$ & sell-control & 0 \\
\hline $22+2+2>3$ & 115 & 308 & 1 & 12 & 19 & 16 & 44 & Freq. & Self-esteem & 7 \\
\hline 22 & 1.15 & 3.90 & 1.1 & 13.0 & 20.7 & 17.4 & 47.8 & $\%$ & sen-esteen & 7 \\
\hline & 106 & & 1 & 10 & 17 & 27 & 37 & Freq. & Anplication of correct eating hahits & 8 \\
\hline 27 & 1.06 & 3.97 & 1.1 & 10.9 & 18.5 & 29.3 & 40.2 & $\%$ & Application of correct eating habits & 8 \\
\hline 1 & & & $\mathrm{o}$ & 4 & 31 & 23 & 34 & Freq. & Problem-solving & \\
\hline 1 & 0.94 & 3.95 & $\mathrm{o}$ & 4.3 & 33.7 & 25.0 & 37.0 & $\%$ & Problem-solving & 9 \\
\hline 7 & 15 & 387 & 4 & 5 & 28 & 17 & 38 & Freq. & Planning to achieve $\sigma_{0}$ als & 10 \\
\hline 7 & 1.15 & 3.07 & $4 \cdot 3$ & 5.4 & 30.4 & 18.5 & 41.3 & $\%$ & Planning to acnieve goals & 10 \\
\hline 6 & 17 & 80 & 3 & 9 & 28 & 15 & 37 & Freq. & Establishing personal goals & 1 \\
\hline 0 & 1.17 & 3.80 & $3 \cdot 3$ & 9.8 & 30.4 & 16.3 & 40.2 & $\%$ & & 11 \\
\hline & & & 6 & 9 & 23 & 16 & 38 & Freq. & Memory activation & \\
\hline 9 & 1.27 & 3.77 & 6.5 & 9.8 & 25.0 & 17.4 & 41.3 & $\%$ & & 12 \\
\hline & 18 & & 2 & 14 & 22 & 19 & 35 & Freq. & Collecting information from different & \\
\hline 10 & 1.18 & 3.77 & 2.2 & 15.2 & 23.9 & 20.7 & 38.0 & $\%$ & sources & 13 \\
\hline 15 & 107 & & & 14 & 24 & 25 & 29 & Freq. & Teamwork & 4 \\
\hline 15 & 1.07 & 3.75 & & 15.2 & 26.1 & 27.2 & 31.5 & $\%$ & & 14 \\
\hline 11 & 115 & & 6 & 4 & 27 & 26 & 29 & Freq. & Dialog with others & 15 \\
\hline 11 & 1.15 & 3.74 & 6.5 & $4 \cdot 3$ & $29 \cdot 3$ & 28.3 & 31.5 & $\%$ & & 15 \\
\hline 4 & 18 & & 7 & 3 & 27 & 25 & 30 & Freq. & Treating children & 16 \\
\hline 14 & 1.18 & 3.74 & 7.6 & $3 \cdot 3$ & $29 \cdot 3$ & 27.2 & 32.6 & $\%$ & & 16 \\
\hline 5 & 1.08 & 3.73 & 4 & 5 & 30 & 26 & 27 & Freq. & Management of financial resources & 17 \\
\hline 5 & & $3 \cdot 73$ & $4 \cdot 3$ & 5.4 & 32.6 & 28.3 & $29 \cdot 3$ & $\%$ & & 17 \\
\hline 13 & 32 & 3.72 & 4 & 15 & 16 & 25 & 32 & Freq. & Self-expression & 18 \\
\hline 13 & $1.3^{2}$ & $3 \cdot 72$ & $4 \cdot 3$ & 16.3 & 17.4 & 27.2 & 34.8 & $\%$ & & \\
\hline & & & 5 & 15 & 18 & 18 & 36 & Freq. & & \\
\hline 4 & 1.29 & $3 \cdot 71$ & 5.4 & 16.3 & 19.6 & 19.6 & 39.1 & $\%$ & Time management & 19 \\
\hline 12 & 10 & 363 & 3 & 15 & 25 & 19 & 30 & Freq. & Listening to the other oninion & 20 \\
\hline 12 & 1.19 & 3.03 & $3 \cdot 3$ & 16.3 & 27.2 & 20.7 & 32.6 & $\%$ & & 20 \\
\hline & 21 & & 9 & 8 & 30 & 13 & 32 & Freq. & Rationalization of consumption of the & \\
\hline 19 & 1.31 & $3 \cdot 55$ & 9.8 & 8.7 & 32.6 & 14.1 & 34.8 & $\%$ & available resources & 21 \\
\hline 20 & ר? & & 9 & 12 & 20 & 21 & 30 & Freq. & Waste recycling & 2 \\
\hline 20 & 1.33 & 3.55 & 9.8 & 13.0 & 21.7 & 22.8 & 32.6 & $\%$ & & 22 \\
\hline 8 & 1.34 & & 10 & 11 & 20 & 22 & 29 & Freq. & Self-learning & \\
\hline 8 & 1.34 & $3 \cdot 53$ & 10.9 & 12.0 & 21.7 & 23.9 & 31.5 & $\%$ & & 23 \\
\hline 16 & 8 & & 6 & 13 & 24 & 28 & 21 & Freq. & ting therc' differencec & 4 \\
\hline 16 & 1.18 & 3.49 & 6.5 & 14.1 & 26.1 & 30.4 & 22.8 & $\%$ & ting others differences & 24 \\
\hline 8 & 120 & 3.46 & 10 & 17 & 15 & 21 & 29 & Freq. & Treating children & 25 \\
\hline 10 & 1.39 & 3.40 & 10.9 & 18.5 & 16.3 & 22.8 & 31.5 & $\%$ & & 25 \\
\hline 28 & & & 9 & 13 & 27 & 14 & 29 & Freq. & Protecting the environment & 26 \\
\hline 28 & 1.33 & 3.45 & 9.8 & 14.1 & 29.3 & 15.2 & 31.5 & $\%$ & Protecting the environment & 26 \\
\hline 17 & ר? & & 12 & 12 & 20 & 26 & 22 & Freq. & ring work and family & 7 \\
\hline 17 & 1.33 & $3 \cdot 37$ & 13.0 & 13.0 & 21.7 & 28.3 & 23.9 & $\%$ & Ddancing work dna Idmily & 27 \\
\hline 2 & 100 & 328 & 6 & 7 & 45 & 23 & 11 & Freq. & Critical thinking & 28 \\
\hline 2 & 1.00 & 3.28 & 6.5 & 7.6 & 48.9 & 25.0 & 12.0 & $\%$ & & 28 \\
\hline & 3.76 & & & & & & & rall mean & & \\
\hline
\end{tabular}


Table (9) shows that the overall mean of the life skills required by the disabled students at King Abdulaziz University was (3.76), suggesting that their need was above average. The participants' responses scored (3.28-4.17) ranging from average to above average. While "application of the first aid principles" was ranked the highest, "critical thinking" was ranked the lowest.

The table shows that the highest skills were "application of the first aid principles, creative thinking, and stress management" because the activities play a significant and effective role in them. With proper planning and restructuring the system of activities to suit the disabled, they may achieve greater development. For example, application of the first aid principles is an essential life skill that requires practice that can be allowed by the activities.

The students chose "stress management" in answering the first and second questions as the best skill that activities help to develop and still needs much development. That is, the students are aware of its importance and refinement with further activities.

In a nutshell, the inventory of the most required skills can help make recommendations that stress the importance of student activities in the development of life skills. It also highlights the skills to be developed and promotes the developed ones.

This result agrees with Bayounis (2016) reporting that one of the most significant life skills is "first aid principles". It differs from Mahmoud and Mohamed (2014) that the level of life skills among university students is good. It also disagrees with Zareaa (2009) that concludes that "decision-making and reflective thinking" are ranked the highest.

\section{Recommendations}

The author recommends:

1- Including life skills required for the disabled students in the courses of Saudi universities.

2- Including student activities that consider life skills of the disabled students in the courses to form a basis of human behavior and to facilitate handling the different life situations.

3- Interest in designing courses based on activities that develop life skills, including appropriate authentic situations, for ongoing qualification and adaptation to life requirements.

4- Designing a teacher's guide for the implementation of student activities, taking into account the development of life skills that are appropriate for disabled students.

5- Holding seminars, training courses, and workshops on student activities and life skills of the disabled students for supervisors, teachers, and faculty members.

\section{Acknowledgement}

This project was funded by the Deanship of Scientific Research (DSR),King Abdulaziz University, Jeddah, under grant No. (1439/279/99). The author, therefore, acknowledge with thanks DSR technical and financial support.

\section{References}

Abdulaleem, R. (2007). Student activities and their role in confronting political violence among the students of AlAzhar University: A field study. Journal of Faculty of Education- Tanta University, 1(36), 106-203.

Abdulhaseeb, G. (2010). The practice of student activities among Qassim University's students “a field study”. Journal of Education- Ain Shams University, 4(34), 175-241.

Abdulmonem, S. (2013). The role of extracurricular activities in promoting loyalty among university students in Gaza: A field study. Presented at the first international conference of "University Students: Reality and Aspirations" (pp. 306-331). Gaza: The Deanship of Student Affairs, the Islamic University-Gaza.

Abdulmoatey, A. \& Mostafa, D. (2007). Life skills. Cairo: Dar Elsahab for Publishing and Distribution

Abudalyouh, M. (2011). The effectiveness of student activities at Yarmouk University from the students' perspective. Journal of Education-Al-Azhar University, 5(146), 257-293.

Abuhajar, F. (2011). The role of educational activities in developing life skills. Jordan: Taif for Educational Services.

Abulelaa, D. (2018). The role of student activities in developing community participation among students with special needs (a case study). Journal of Alexandria University, 4(93), 1-61. 
Alattom, M. (2008). Contemporary school activity: Theory and practice. Jordan: Dar Al-Manahej.

Alfera, A. (2015). The role of university activities in developing national awareness based on the political involvement of the students of Palestinian universities from their perspective. Journal of Al-Azhar University-Gaza, 17(2), 95-124.

Algedeby, R. (2010). Life skills among high stage students based on contemporary challenges and attitudes- an Islamic educational perspective (Ph.D. dissertation). College of Education, Umm Al-Qura University.

Alharby, Q. (2017). Developing citizenship among students of Saudi universities (Jazan University as a model). Journal of the Faculty of Education- Al-Azhar University, 176(1), $13-54$.

Alharethy, S. (2010). Effectiveness of a psychological counseling program for the development of life skills among high school students in Taif Governorate. Journal of Specific Education Research, 16, 34-80.

Alhelwa, T. (2014). Life skills among the students of Princess Nora Bint Abdulrahman University in the light of contemporary challenges. Journal of Educational Sciences, 3(2), 177-218.

Aljaweesh, M. (2007). Basics of educational activities. Alexandria: Horus International.

Almahameed, H. and Samreen, H. (2010). Obstacles to teaching life skills from the perspectives of the teachers of vocational education and physical education in Albadaea Alwasta Directorate of Education in Jordan. Jordan of the Faculty of Education- Ain Shams University, 4(34), 135-171.

Alnajey, A. (2009). What are the skills required for secondary school students? Accessed online http://www.almarefh.net/show_content_sub.php?CUV=357\&SubModel=138\&ID=320.

Alomarey, G. (2013). Awareness of the students of the public Jordanian universities of life skills in the light of knowledge economy. Journal of Educational and Psychological Studies, 10, 103-128.

Alqraiti, A. (2010). Inclusion of special needs in general education: Consequences, benefits, forms, and prerequisites. Journal of Psychological Guidance- Ain Shams University, 24, 27-25.

Alwell, M. \& Cobb, B. (2009). Functional life skills curricular interventions for youth with disabilities: a systematic review. Career Development for Exceptional Individuals, 32(2),82-93.

Aly, S. (2014). Effectiveness of a program based on e-learning strategies in the development of some life skills among teachable children with mental disabilities. Journal of the Faculty of Education-Port Said University, 16, 630-650.

Arandes, A. (2017). The relationship between the practice of student activities and educational outcomes among the students of Menoufia University: A field study (MA. thesis). Faculty of Education, Menoufia University.

Arrefaey, S. (2007). Procedures for student activity. Jeddah: Khawarizm Academic.

Attahrawey, G. and Abukosh, Y. (2013). The role of extracurricular activities in satisfying the psychological needs of the Islamic University's students based on Maslow's theory. Presented at the first international conference "University Students: Reality and Aspirations" (pp. 117-137). Gaza: The Deanship of Student Affairs, the Islamic University-Gaza.

Assayed, M. (2007). The need for life skills among Israa University students. Journal of the Association of Arab Universities for Research in Higher Education, 49, 103-141.

Attia, A. (2007). The effectiveness of an activity-based module in social studies in developing the life skills of the primary stage students. Journal of the Educational Association of Social Studies, 48-98.

Attia, R. (2018). Problems to the practice of activities among university students: A field study on a sample of the students of Delta Academy of Science (MA. thesis). Faculty of Arts, Mansoura University.

Azzobiany, M. (2002). Attitudes of the high school students in Madina towards engagement in the programs of school activity and their factors. Mission of the Arab GulfJournal, 88, 118-182.

Bakheet, K. (2011). Effectiveness of university study in developing some life skills- a field study. The $7^{\text {th }}$ Annual National Conference of University Education Development Center (pp. 123-166).

Baroum, S. (2012). University education programs and developing the skills of future management: A study on the students of King Abdulaziz University. Majmaa Journal, 3, 91-151.

Bayounis, S. (2016). Contribution of student activities in the development of students' life skills at King Abdulaziz University (MA. thesis). Faculty of Home Economics, King Abdulaziz University.

Fayez, M. (2017). The role of recreational camps in developing life skills among the students of Mansoura University (MA. thesis). Faculty of Physical Education, Mansoura University.

Gomes, A. \& Marques, B. (2013). Life skills in educational contexts: Testing the effects of an intervention programme. Educational Studies, 39 (2), 156-166. https://doi.org/10.1080/03055698.2012.689813.

Hammad, K. and Allouh, A. (2013). Acceptance and willingness of the students of the Islamic University to engage in student activities. Presented at the first international conference of "University Students: Reality and Aspirations" (pp. 272-305). Gaza: The Deanship of Student Affairs, the Islamic University-Gaza.

Hasan, A. (2009). Impact of Wheatly Model-based teaching on the achievement and attitude of the $6^{\text {th }}$ year basic students in the course of science. Egyptian Council for Curriculum \& Instruction, 137. Available: http://www.unicef.org/arabic/lifeskills/lifeskills_25521.html. 
Ibrahim, M. (2019). On the role of recreational camps in developing some life skills among the students of Mansoura University (MA. thesis). Faculty of Physical Education, Mansoura University.

Jones, M. \& Lavallee, D. (2009). Exploring the life skills needs of British adolescent athletes. Psychology of Sport and Exercise, 10(1), 159-167. https://doi.org/10.1016/j.psychsport.2008.06.005.

Kagan, S. (2013). Skills for life for children. South Sudan: Ministry of Education, Science and Technology. www.unesdoc.unesco.org/images/o023/o02322/232257E.pdf.

Kelab, A. (2018). A suggested proposal for developing student activities role in Palestinian universities in promoting national unity among students (MA. thesis). Faculty of Education, the Islamic University- Gaza.

Mahmoud, L. \& Mohamed, D. (2014). Life skills among university students. Journal of the University of Diyala, 23, 111-137.

Mansour, A. (2010). Management and supervision in special education. Riyadh: Dar Alzahraa.

Masoud, R. (2002). The effectiveness of cooperative learning strategy in teaching social studies on developing life skills, achievement, and attitude towards the subject among the first-year preparatory students. Studies in Curriculum and Instruction, 8, 43-80.

Maziu, M. (2014). The educational role of student activities in developing some educational principles among the intermediate stage students in Tabuk. Journal of Educational Sciences, 1(4), 565-602.

Mina, F. (2004). University activities in the knowledge society. A paper presented at the $11^{\text {th }}$ Annual National- $3^{\text {rd }}$ Arab Conference "Arab University Education: Reformation and Development Horizons. University Development Center, Ain Shams University, Cairo.

Ministry of Education in the Sultanate of Oman. (2010). Program of life skills: Work portfolio. Riyadh: The Arab Bureau of Education for the Gulf States.

Mujahid, M. (2008). Culture of standards and quality of education. Cairo: Dar Alfirk Alaraby.

Mustafa, O. (2017). A proposed module of human resources in the student activity department, University of ZawiaLibya (MA. thesis). Faculty of Physical Education for Women, Alexandria University.

Othman, R. \& Qamar, E. (2009). Student activity: Theory, international experiences, and scientific applications. Jordan: Dar Alfikr.

Ouda, A. (2008). Impact of utilizing metacognitive skills on developing scientific concepts and life skills in the course of science among the $5^{\text {th }}$ year basic students in Gaza (MA. thesis). Faculty of Education, the Islamic University-Gaza.

Qanadeely, G. (2006). Student services. Cairo: Professional Management Expertise Center.

Rajab, A. (2019). Impact of practicing the student activities on the inclusion of special needs: A case study of the students with motor disability at Mansoura University (Ph.D. dissertation). Faculty of Arts, at Mansoura University.

Qasayma, M. \& Akbar, F. (2010). Student activities and the educational curriculum: A modern perspective. Jeddah: Khawarizm Academic.

Rashwan, A. \& Adel, A. (2009). The effectiveness of an active learning-based program in developing life skills among the students of the one-room school. Paper presented at the Fourth Scientific Conference-Education and Future Challenges, 1, 221-277.

Saad-eddin, H. (2007). Life skills embedded in the course of technology for the $10^{\text {th }}$ grade and student learning (MA. thesis). Faculty of Education, the Islamic University-Gaza.

Sasila, R. (2011). The role of the Faculty of Education- Damascus University in developing life skills in the light of the contemporary educational trends. Journal of the Association of Arab Universities for Education and Psychology, 9(4), 161-190.

Shaaban, D. (2009). Effectiveness of a program in the development of some life skills among children with multipledisabilities (MA. thesis). Faculty of Kindergarten, Fayoum University.

Shaldan, F. \& Alnadeem, R. (2013). Reasons for and ways of overcoming the reluctance of the students of the Islamic University- Gaza to engage in university activities. Presented at the first international conference "University Students: Reality and Aspirations" (pp. 73-99). Gaza: The Deanship of Student Affairs, the Islamic University-Gaza.

UNICEF (2005). What skills are life skills? Available at: https://www.unicef.org/arabic/lifeskills/lifeskills_25521.html.

Utah State Office of Education (2006). A guide to knowledge, skills and disposition for success /Grade K-12. Utah: Utah State Office of Education.

Wafy, A. (2011). Life skills and relationships to multi-intelligences among secondary school students in Gaza (MA. thesis). Faculty of Education, the Islamic University-Gaza.

Zareaa, A. (2009). The effectiveness of a proposed training program of social studies' student-teacher qualification in developing some life skills and awareness of the educational challenges of globalization. Paper presented at the Second Scientific Conference "The Role of the Arab Teacher at the Age of the Flow of Knowledge", Jerash University, Jordan. 